
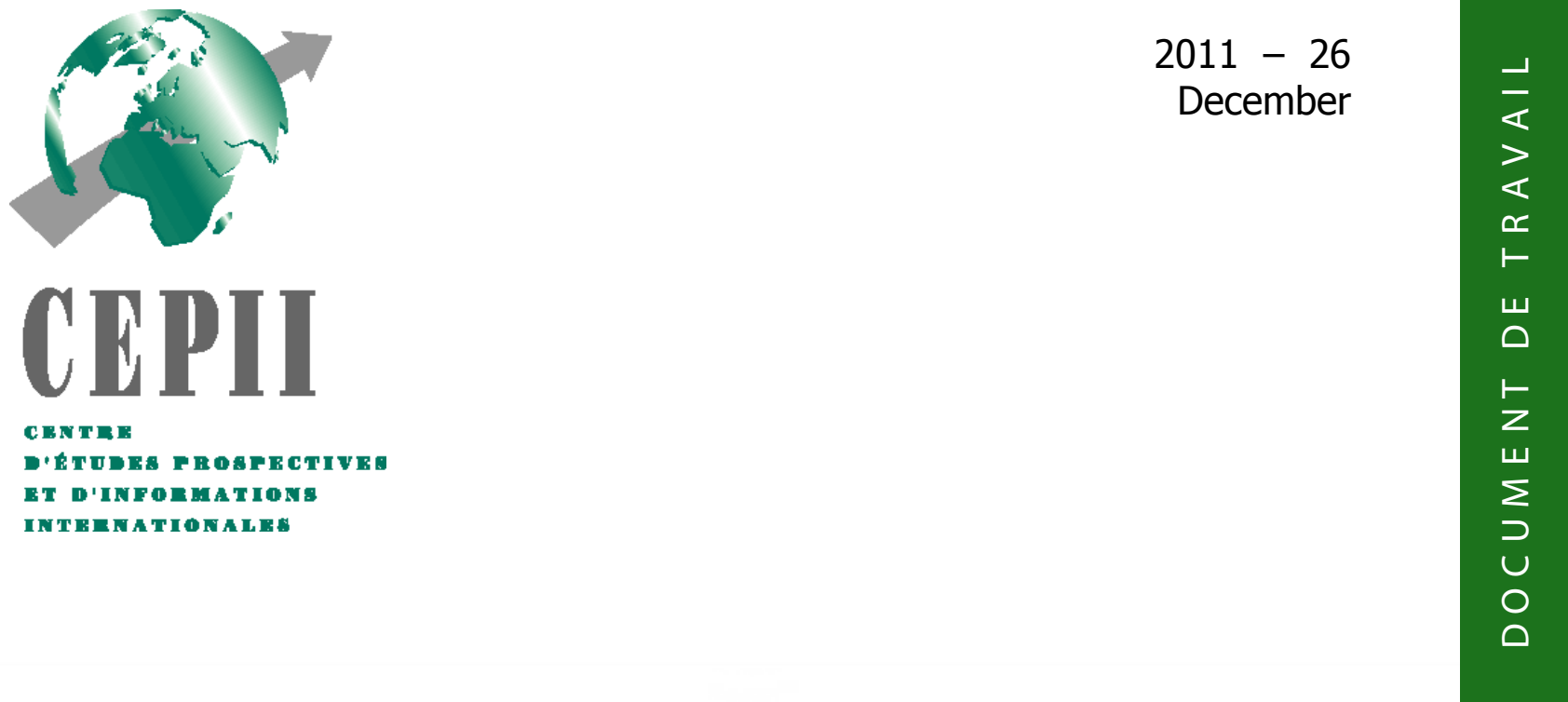

Isolating the Network Effect of Immigrants on Trade

Mariya Aleksynska, Giovanni Peri 


\section{TABLE OF CONTENTS}

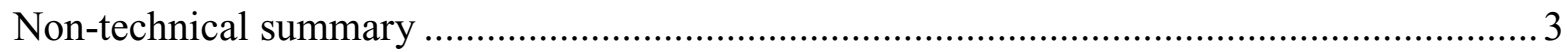

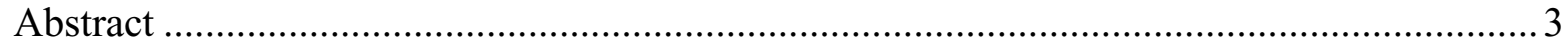

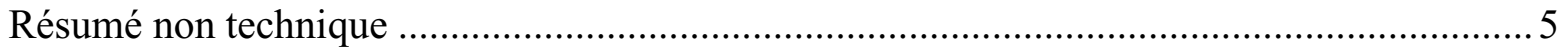

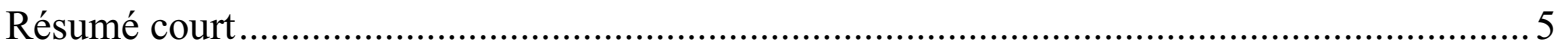

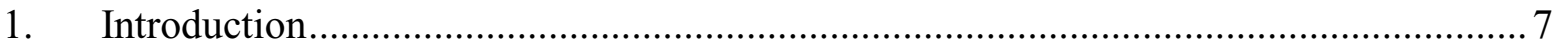

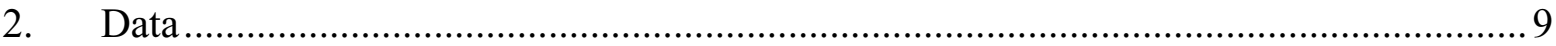

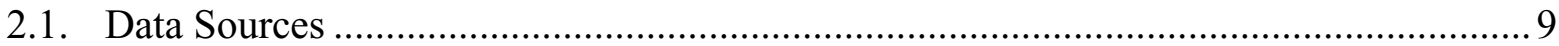

2.2. Business Network Immigrants: Definitions................................................................. 10

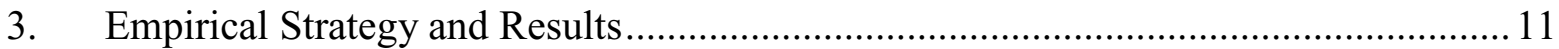

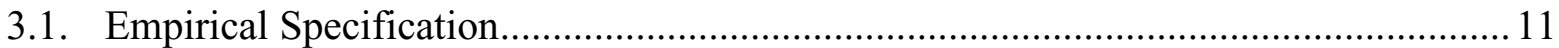

3.2. Aggregate Business Networks and Aggregate Trade ............................................. 12

3.3. Business networks and Trade of Homogeneous and Differentiated Goods ................ 15

3.4. Business Networks: Occupational or Educational Effect? ........................................ 15

3.5. Interactions of Business Networks with Common Factors.......................................... 17

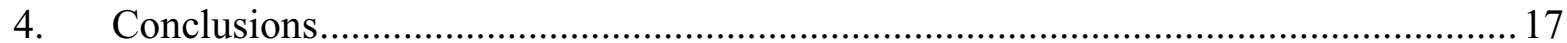

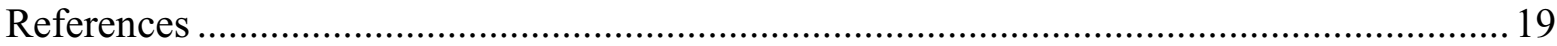

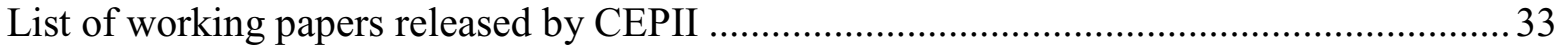




\title{
ISOLATING THE NETWORK EFFECT OF IMMIGRANTS ON TRADE
}

\section{NON-TECHNICAL SUMMARY}

There is a large literature that suggests a strong, stable and significant empirical connection between the number of immigrants in a receiving country and the amount of trade with their country of origin. These studies have been taken as evidence that the positive immigrationtrade correlation is driven by network effects: immigrants make it easier for domestic firms to export as they lower information barriers and therefore the fixed cost of accessing new markets characterized by different culture and business practices.

The existing literature, however, has always equated the total number of migrants to the size of the business network that enhances trade between countries. What has been lacking is an effort to measure more precisely the size of the business network established by immigrants and its direct effects on trade. To do this, one needs to identify how large is the group of immigrants that may facilitate the commercial relations between the host and the origin countries. In this paper, we propose a more precise measure of the trade business network of immigrants than previously used. Using the newly released data on immigrant occupations from OECD, we consider in each country those immigrants in managerial jobs that are pivotal to establishing important business connections. We analyze how this group affects trade.

Our findings suggest that each business network immigrant generates over ten times the value of trade than a non-business network immigrant does. The share of business network immigrants is a better predictor of trade than the share of highly educated immigrants. When we use the occupational and education categories together, we find that only highly educated immigrants in business network occupations enhance trade.

We also identify what type of bilateral trade relations are particularly boosted by business network migrants. We show that business networks are especially trade-enhancing between countries with different legal origin.

\begin{abstract}
Within the migration-trade nexus literature, this paper proposes a more carefully defined measure of migration business networks, and quantifies its impact on bilateral trade. Controlling for the overall bilateral stock of migrants, the share of migrants employed in managerial/business-related occupations has a strong additional effect on trade, and especially on exports. Those immigrants should be the ones directly involved in the diffusion of relevant information for trading companies. Their presence, more than the presence of immigrants overall, or of highly educated immigrants, is found to enhance trade. When we control for the
\end{abstract}


presence of highly educated immigrants, the share of immigrants in business network occupations shows a particularly large effect on trade in differentiated goods. Specifically, we find that highly educated individuals in business-related occupations are those enhancing export by the largest margin. Business network effect is particularly important for culturally different countries, such as the ones with different legal origin.

JEL Classification: F14, F16, F22.

Key Words: Migration, International Trade, Business Networks, Differentiated Goods. 


\section{IMMIGRÉS ET COMMERCE INTERNATIONAL : MIEUX APPRÉHENDER LES EFFETS DE RÉSEAU}

\section{RÉSUMÉ NON TECHNIQUE}

Une vaste littérature empirique suggère qu'il existe un lien solide, stable et significatif entre le nombre d'immigrés dans un pays et le montant des échanges commerciaux entre ce pays et les pays d'origine des immigrés. La corrélation entre l'immigration et les échanges commerciaux s'expliquerait par des effets de réseau: les immigrés faciliteraient les exportations des entreprises nationales car, en abaissant les barrières à l'information, ils réduiraient les coûts fixes d'accès à de nouveaux marchés aux cultures et pratiques différentes.

Cependant, la littérature existante a toujours assimilé la taille du réseau d'affaires au nombre total de migrants. Il nous a semblé nécessaire de mieux identifier la taille du groupe des immigrants susceptibles de faciliter les relations commerciales entre le pays d'accueil et les pays d'origine. En utilisant la nouvelle base de données de l'OCDE sur l'immigration, renseignée par occupations, nous considérons dans chaque pays que les immigrés employés à des niveaux de responsabilité dans des tâches centrales pour l'établissement de relations d'affaires. Nous analysons comment ce groupe affecte les échanges entre les pays.

Nos résultats suggèrent que chaque immigré appartenant au réseau d'affaires génère plus de dix fois la valeur des échanges qu'un immigré moyen. La proportion parmi les immigrés de ceux appartenant au réseau d'affaires est un meilleur prédicateur du commerce que celle des immigrés hautement qualifiés. Lorsque nous utilisons à la fois les critères de catégorie professionnelle et de niveau d'études, nous constatons que seuls les immigrés hautement qualifiés des professions appartenant au réseau d'affaires stimulent le commerce.

Nous avons aussi cherché à identifier quel type de relations commerciales bilatérales sont particulièrement affectées par les réseaux d'affaires. Nous montrons que ces réseaux favorisent particulièrement les échanges entre pays aux traditions juridiques différentes.

\section{RÉSUMÉ COURT}

Dans le cadre de la littérature sur les liens entre migrations et commerce, cet article propose une mesure plus soigneusement définie des réseaux d'affaires des immigrés et quantifie son influence sur le commerce. Nous montrons que la part des migrants dans les réseaux d'affaires a un fort effet sur le commerce, en particulier sur les exportations. Leur présence, plus que celle des immigrés dans leur ensemble, ou celle des immigrés hautement qualifiés, 
renforce le commerce. Lorsque nous utilisons à la fois les critères de catégorie professionnelle et de niveau d'études, nous constatons que seuls les immigrés hautement qualifiés des professions appartenant au réseau d'affaires stimulent le commerce, particulièrement celui de produits différenciés. L'effet de réseau d'affaires est particulièrement important vis à vis des pays culturellement différents, notamment ceux aux traditions juridiques différentes.

Classification JEL : F14, F16, F22.

Mots-clefs : migration, commerce international, réseaux d'affaires, produits différenciés. 


\title{
ISOLATING THE NETWORK EFFECT OF IMMIGRANTS ON TRADE
}

\author{
Mariya Aleksynska ${ }^{1}$, Giovanni Peri ${ }^{2}$
}

\section{INTRODUCTION}

Beginning with the seminal contributions of Gould (1994) and Head and Ries (1998), several recent papers have found a strong, stable and significant empirical correlation between the stock of immigrants in the receiving country and the amount of trade with their country of origin $^{3}$. In several refinements these studies have analyzed the impact of immigration on differentiated versus homogeneous exports, on imports and exports, and on exports of final and intermediate goods. Combining these studies, the overall evidence shows larger effects for exports than for imports, for differentiated than for homogeneous goods, and between culturally distant countries. All these results have been taken as evidence that the positive immigration-trade correlation is driven by network effects: immigrants make it easier for domestic firms to export as they lower information barriers and therefore the fixed cost of accessing new markets characterized by different culture and business practices.

This literature, however, has always equated the total number of bilateral migrants to the size of the business network that enhances bilateral trade. What has been lacking from it is an effort to measure more precisely the size of the business network established by immigrants and its direct effects on trade. To do this, one needs to identify how large is the group of immigrants that may facilitate the commercial relations between the host and the origin countries. The only variable used as proxy for this in the literature, so far, is the total number of immigrants. However, there are three reasons to believe that total immigrant population is a very poor and noisy measure of the business networks established by immigrants and it may capture several other spurious variables. First, many immigrants into OECD countries have found employment in non-tradable service sectors such as construction, personal services, household service, hospitality and food services. In contrast, most of the exports are done by firms in the manufacturing sector. There is no clear connection between those immigrants and the export activity of manufacturing firms. Second, large aggregate immigration flows from a country may very well imply some preference in the bilateral relationship or some cultural

\footnotetext{
${ }^{1}$ Corresponding Author: CEPII, 113 rue de Grenelle, 75007 Paris, France. Maria.aleksynska@cepii.fr

2 Department of Economics, UC Davis, One Shields Avenue Davis CA 95616. gperi@ucdavis.edu We would like to thank, without implicating, Lionel Ragot, Matthieu Crozet, Maelan Le Goff, Agnès Chevallier, Agnès Bénassy-Quéré, Christophe Destais and Gunther Capelle Blancard for their comments on the initial draft of the paper. The usual disclaimer applies.

3 A partial list includes Dunlevy and Hutchinson (1999), Girma and Yu (2002), Wagner et al. (2002), Rauch and Trindale (2002), Combes et al. (2005), Dunlevy (2006), Bandyopadhyay et al. (2008), Felbermayr and Toubal (forthcoming).
} 
connection that may also affect trade. These special bilateral relationships may be hard to measure and hence may bias the estimated coefficient of immigration on trade upwards. Finally, while some recent studies have considered special sub-groups of immigrants (such as highly educated ones in Felbermayr and Jung, 2009) as more relevant for trade, they have not effectively identified those immigrants as actually participating to the trade-business network. If immigrants suffer from poor skill transferability and skill downgrading (Chiswick and Miller, 2009), their occupation in the destination country, rather than their schooling, could be a better measure of their productive contribution and their role in enhancing trade.

This paper proposes a more precise measure of the trade business network of immigrants. Using the newly released data on immigrant occupations from OECD (2010), the DIOC-E database, we consider in each country those immigrants in managerial jobs that are pivotal to establishing important business connections. We analyze how this group affects trade, once we control for total immigrant flows. The estimated coefficient is a more precise measure of the direct information-diffusion effect on trade channeled by business networks of international migrants.

A first look at the data and at some stylized statistics suggests that capturing the intensity of bilateral business network with the number (or share) of bilateral migrants can introduce very large measurement error in the analysis. Table 1 shows (in column 1) the share of immigrants in the population for all European countries. It also shows, in column 2, the percentage of immigrants in occupations as business directors or managers (ISCO-1 group of the ISCO occupational classification) that are directly responsible for creating international business relations and export opportunities. We will call this group the "business network immigrants". Columns 3 and 4 show also the share of immigrants in occupations less directly related to international business networks but still linked to marketing and sales (market salespersons, ISCO-5, and door-to-door and telephone salespersons, ISCO-9). It is easy to notice that countries with similar overall share of immigrants, such as for instance, Ireland and Germany, have a very different percentage of them involved in the "business network" as represented by the most relevant occupations of "business manager and directors". In Ireland, 16\% of immigrants are employed in those occupations while in Germany essentially no immigrant is.

Even more interesting as stylized fact are Figures $1 \mathrm{a}$ and $1 \mathrm{~b}$. These figures report the correlation between openness to trade and migration shares for four selected EU countries that are both diverse and representative as destination countries (Portugal, UK, Spain and France) and their main migration-origin countries. Figure 1a reports clear positive correlation in each of those countries between business network immigrants from a country (as share of total immigrant stock from this country) and the trade towards that specific country. For instance, France exports a lot to Germany, the UK exports a lot to the US, and Portugal to Spain. Correspondingly, migrants from those countries involved in business networks occupations are large fractions of the migrant population. In contrast, Figure $1 \mathrm{~b}$ shows that the same positive correlation does not hold between the stock of migrants from top destination countries (as share of total migrant population in a receiving country) and trade: Germany, US and Spain do not provide, in relative terms, large migrants flow to France, the UK and Portugal. Furthermore, trade between largest immigrant-partner countries, such as Morocco and Spain, or Angola and Portugal, is relatively limited. 
Our findings are reasonably strong and robust. Controlling for the bilateral stock of migrants, which can be correlated with several unobserved bilateral variables, the share of migrants in business network occupations has a large and significant effect on export (and much less on imports). Specifically, each business network immigrant generates over ten times the value of trade than a non-business network immigrant does. The share of business network immigrants works better than the share of highly educated immigrants in predicting trade and it shows a particularly large effect on trade in differentiated goods (although it has also a significant effect on trade of homogeneous goods). When we use the occupational and education categories together, we find that only highly educated immigrants in business network occupations enhance trade.

By interacting the presence of business network immigrants and specific bilateral characteristics, we also identify what type of bilateral trade relations are particularly boosted by business network migrants. For instance, if business networks are catalysts of informational exchange and conductors of norms and rules (as argued in Rauch, 1999) they should be particularly important in facilitating trade between more culturally distant countries. We show that business networks are especially trade-enhancing between countries with different legal origin. At the same time, cultural similarities (linguistic, colonial origin, but not religion) attenuate the effect of business networks on trade.

The rest of the paper is organized as follows. Section 2 describes the data. Section 3 outlines the empirical strategy and discusses the results. The last section concludes.

\section{DATA}

\subsection{Data Sources}

The data on bilateral stocks of migrants are obtained from the newly released OECD DIOC-E database, which covers 89 destination countries and 233 countries of origin ${ }^{4}$. It includes information on 110 million migrants who are at least 15 years old, which represents around $72 \%$ of all international migrants (Dumont, Spielvogel, Widmaier, 2010). Immigrants are distinguished by age, gender, schooling level, labor market status and, most importantly, occupation, using the 1-digit level ISCO classification. These data are compiled using numerous national sources, mainly censuses and population surveys. They are available for a cross-section of countries. Most of the data collected are relative to the year 2000-2002. A few countries are included for which the reference year is a bit earlier (1996 for Uruguay) or somewhat later (2005 for Nicaragua). A few countries, namely USA, Argentina, Turkey, and Japan, use an occupational classification very different from ISCO. They are thus excluded from the analysis. This is regrettable, but the worry is that the inclusion of these countries and specifying business networks through a different methodology for these countries may introduce unnecessary noise to the data.

\footnotetext{
4 The database is not "square", however. In some countries, like Greece, information on up to 206 origin sources is available, in others, like the Netherlands, only the four largest countries of origin are known. On average, there are 96 migrant origin countries per destination.
} 
Data on bilateral trade flows come from two sources. First, the total value of imports and exports is from the CEPII "square" gravity dataset compiled by Head, Mayer and Ries (2010). This database also contains the set of all other standard gravity variables, such as geographical distance between countries, information on contiguity, common language, past colonial ties, and a dummy RTA for having a Regional Trade Agreement in place. The bilateral trade data are merged with the bilateral migration data using the year in which the migration data are observed. Trade data are unavailable for some origin countries, such as the Democratic Republic of Congo, or Serbia and Montenegro, as well as for some country-pairs. Thus, the final dataset used for the empirical analysis contains 4923 non-zero observations for exports, and 4806 non-zero observations for imports (5230 observations for both imports and exports, if zero trade flows are included). The descriptions of the variables and the summary statistics for each one of them are reported in Table 1 of Appendix 1.

Second, to distinguish trade between homogeneous, moderately differentiated, and highly differentiated goods, we use CEPII-BACI data disaggregated at 6-digit product level (Gaulier and Zignago, 2007). These data are matched with the estimated elasticities of Broda and Weinstein (2006) that characterize the degree of differentiation of products within sector. We first use the correspondence table between 6-digit Harmonized Commodity Description and Coding System (HS-6) and the 5-digit SITC Revision 3 nomenclature. The products are further aggregated into three categories according to their elasticity of substitution into homogeneous goods (elasticity above 3.5), moderately differentiated goods (between 2 and 3.5), and highly differentiated products (below 2).

\subsection{Business Network Immigrants: Definitions}

Using the OECD DIOC-E database, we measure the size of a bilateral business network as the number of immigrants who work in the destination country in business network occupations. As we mentioned in the introduction, occupations classified under Group 1 of the one-digit occupational ISCO classification are those likely to be most relevant to establish international business relations and networks. They include jobs such as senior government officials official in special interest organizations, and managers of enterprises (see Appendix 2 for the full list of occupations under this Group). Government officials may promote trade between countries through their capability to establish long-lasting contacts, initiate bilateral and multilateral relations and influence specific trade policies. Top-level managers are the key decision makers on international activities of their companies, and they are directly involved in their realization. These professionals have a direct role in channeling relevant information and knowledge of potential export markets, and in facilitating the understanding of cultural and business practice differences.

We have also examined other occupations which may be related to trade and its networks. Specifically, individuals employed in occupations within Group 5 (shop, stall and market salespersons and demonstrators) may also perform some of the business-related functions, although at a lower level of responsibility. Also, occupations in Group 9 (sales and services 
elementary occupations, street vendors, and door-to-door and telephone salespersons - see Appendix 3) may likewise play a role in creating trade connections, especially in trade in heterogeneous and cultural goods. However, as Groups 5 and 9 also contain numerous other occupations that are not related to trade in a direct way, immigrants in those groups are likely to be less directly relevant for trade. Immigrants employed in any other occupation are defined as non-business network immigrants ${ }^{5}$.

In several countries business networks as defined above are zero, even if there is a non-zero bilateral stock of immigrants. For the same country-pairs, there are, however, data on the number of immigrants in other occupations. Thus, the empty business networks represent a genuine absence of business-network individuals for some country-pairs, rather than missing or incorrect data. We thus include these countries in the main analysis, and in the linear-inlogs specifications we add one to business migration networks. In the analysis, we check, however, whether including these zero business networks biases the results. In total, there are $77 \%$ non-zero business network observations. The average number of economically active immigrants in a given country-pair is 5118 , while the average number of business migrants is 631.

\section{EMPIRICAL STRATEGY AND RESULTS}

\subsection{Empirical Specification}

We follow the literature that estimates the effect of total migration stock on bilateral trade, using the theory-based gravity-type estimations (Feenstra, 2004). As we have only a crosssection of data available to us, we follow Anderson and Van Wincoop (2003) in the choice of controls and fixed effects. In our main empirical specification, we include the logarithm of the total stock of migrants in the analysis, and also the logarithm of share of migrants in business network occupations. The rest of the specification is fairly standard. Our estimated gravity equation is as follows:

$$
\begin{aligned}
& \ln \left(\mathrm{T}_{\mathrm{sdt}}\right)= \\
& \alpha_{0}+\alpha_{1} \ln \left(\text { share }_{\mathrm{sdt}}^{\mathrm{k}}\right)+\alpha_{2} \ln \left(\text { IMMIGRANT }_{\mathrm{sdt}}\right)+\alpha_{3} \ln \left(\mathrm{y}_{\mathrm{st}} \mathrm{y}_{\mathrm{dt}}\right)+\alpha_{4} \ln \text { Distance }_{\mathrm{sd}}+ \\
& \alpha_{5} \text { Contig }_{\mathrm{sd}}+\alpha_{6} \text { ComLang }_{\mathrm{sd}}+\alpha_{7} \text { Colony }_{\mathrm{sd}}+\alpha_{8} \text { RTA }_{\mathrm{sdt}}+\mathrm{s}_{\mathrm{s}}+\mathrm{d}_{\mathrm{d}}+\mathrm{t}_{\mathrm{t}}+\mathrm{u}_{\mathrm{sdt}}
\end{aligned}
$$

where $\mathrm{T}_{\text {sdt }}$ is the bilateral volume of trade between migration sending (s) and destination countries (d) at time $t$. The specific measure of trade could be, depending on the specifications, total export or total import, or disaggregated export-imports by less-, moderately-, or highly differentiated goods. The variable IMMIGRANT ${ }_{\text {sdt }}$ is the total bilateral stock of active immigrants aged 15+, born in country $s$ and resident of country $d$, at time $t$.

\footnotetext{
5 Some individuals are coded as belonging to the 99th occupation group while there is no such ISCO classification code. These individuals are treated as belonging to non-business networks. Alternatively, we also aggregated them into the Group 9 of 1-digit ISCO aggregation, and this did not affect the estimation results.
} 
The variable share $e_{\text {gdt }}^{k}$ is the count of immigrants, as share of total immigrants, in a specific occupation group $\mathrm{k}$ that proxies for the business network or the non-business network. In particular we have $k \in\{b 1, b 59, b n\}$ where the superscript b1 corresponds to ISCO occupation Group 1, the superscript "b59" corresponds to ISCO occupation Groups 5 and 9 and the superscript "bn" corresponds to all other ISCO occupation-groups, or non-business migrants. The rest of the equation includes standard gravity controls, such as the logarithm of the product of countries' GDPs, the logarithm of the distance, dummies to capture the contiguity between two countries, common language, colonial past, and the presence of regional trade agreements. They all contribute to control for bilateral trade costs. Furthermore, we also include the full set of host-country $d_{d}$ and sending-country $s_{s}$ fixed effects to control for the multilateral resistance terms, as prescribed in Anderson and Van Wincoop (2003) and Baldwin and Taglioni (2006). While the data is a cross-section and hence each county-pair is observed only once, we include dummies $t_{t}$ for the exact year of data collection (as it varies from 1996 to 2005).

\subsection{Aggregate Business Networks and Aggregate Trade}

Table 2 shows the main results of the basic specifications. In columns 1-10, the dependent variable is the logarithm of the total value of bilateral imports or exports in US dollars. This linear-in-logs specification converts the zero trade flows into missing, and thus the sample is restricted to observations with non-zero trade flows.

In Columns 1 and 2 of Table 2 we include only the logarithm of the total number of immigrants employed in occupations of Group 1 (the business networks) as the explanatory variable of interest. The coefficient on this variable is positive and statistically significant for both exports and imports. These regressions, however, combine in one coefficient the direct network effects and the possibly indirect effects of all immigrants as total stock of migrants is not controlled for.

In columns 3-4, we implement our preferred specification. It controls for the logarithm of the total number of immigrants and in addition, we include the log of the share of the business network immigrants in the same bilateral relationship. The coefficient on the log of total migrants is positive and significant in both regressions on imports and exports, and its magnitude is around 0.27 which is within the range of values reported in similar studies ${ }^{6}$. In addition to this, the coefficient on the share of immigrants in business networks occupations is positive, large and statistically significant at 5\% for exports and for imports, suggesting that individuals in business networks have an impact above and beyond that of the total number of migrants on trade. An increase in the share of immigrants employed in the business network occupations by $1 \%$ increases exports by about $0.48 \%$, and imports by about $0.64 \%$, given the same total stock of immigrants and holding all other country-pair variables constant.

\footnotetext{
${ }^{6}$ See Peri and Requena (2010), Table 1, for a survey of recent findings in the literature. Most of the estimates of the elasticity of trade to total migration found in the literature range between 0.1 and 0.25 .
} 
In the remaining columns of Table 2 we check for the robustness of this result to alternative definition of networks. When we consider the share of immigrants in occupations within Groups 5 and 9 we do not find any effects on trade (columns 5 and 6). When both shares of occupations are included simultaneously (columns 7-8), only the share in Groupl has an additional trade-creating effect. Furthermore, the share of immigrant workers in other, nonbusiness, occupations (columns 9-10) does not have a statistically significant effect on trade (and the point estimate is negative) once the total number of migrants is controlled for.

One of the problems with the linear-in-logs specification adopted in columns 1-10 of Table 2 is that the conversion of the zero trade flows into missing values may introduce selection bias and it causes the loss of valuable information. The gravity literature offers several ways of dealing with this problem. First, it is possible to add a small number (usually one) to the actual value of the dependent variable (trade flows), so that zero observations are not lost. We can then perform an OLS estimation based on this new variable. However, there is little guidance to the choice of this small number, and several authors have stressed high sensitivity of the results to the chosen number (see for instance Head et al., 2010). We have augmented the total value of trade by one, and by ten dollars, and found that the magnitude of the coefficient on the share of business immigrants almost doubles in the export regressions and remains statistically significant, while it changes only slightly, in the import regression. In both cases immigrants in the business network remain a significant determinant of imports and exports. These results - not reported in the tables - are available on request.

Alternatively, the literature (Santos Silva and Tenreyro, 2009) suggests employing Poisson maximum likelihood (PMLE) estimation or Tobit estimation, to incorporate zero values of trade. We check the robustness of our results to these estimation methods. Both of them produce consistent estimates only if the error terms satisfy the log normality and homoskedasticity conditions, which is indeed a very strong assumption. In addition, PLME may produce serious bias if the number of zeros is large (Martin and Pham, 2009). In our sample, about $25 \%$ of the observations for imports and $22 \%$ of observations for exports have zero values, which is relatively low (ibid). The results of PMLE estimation are shown in columns 11-12 of Table 2. For exports, these results are similar to the OLS estimates. For imports the coefficient on the logarithm of the share of business network immigrants almost doubles in magnitude. Both coefficients remain highly statistically significant. We also perform Tobit estimation and the results are presented in columns (13) and (14). This technique is somewhat sensitive to the truncation threshold. Following Head et al. (2010) we convert zero trade into $\$ 5000$. Results based on this transformation are similar to those of the OLS regression and consistent with the coefficients obtained by other methods. The similarity of the estimated coefficients across specifications, especially for the elasticity of export to the immigrant business networks, is reassuring and shows that the more simple and robust least 
square estimation performs relatively well. Hence, in what follows, we use the more standard OLS technique based on non-zero trade flows ${ }^{7}$.

Finally, a concern with the cross-sectional type of estimation is the potential joint determination of migration and trade. While the immigration variable is a stock (accumulated over the years) and hence likely to be determined prior to the trade flows, in order to further mitigate this concern, we use the trade data in period $t+2$. By so doing the stock of immigrants is completely predetermined with respect to trade. The effect of business networks is robust to this correction for exports (Table 3, columns 1-2). The effect of immigrant business networks on import however declines and becomes insignificant. All in all the effect of business network immigrants on exports is always significant, robust and rather stable across specifications. To the contrary the effect on import is more unstable and imprecisely estimated. This is preliminary evidence that the specific business network variables is more significant in determining exports, as the theory of information diffusion would suggest. We continue employing trade in period $\mathrm{t}+2$ in all further estimations.

Before moving to more detailed analysis, let us provide the reader with an idea of the magnitude of this effect. Consider a $10 \%$ increase in the average country-pair stock of active migrants. This would amount to an increase from 5118 to 5630 immigrants, or 512 individuals per country-pair. Without taking into account the occupational differences, this increase would lead to a $2.51 \%$ rise in total exports (coefficient on Ln(IMMIGRANTS) from Table 3, column 2). Given that the average value of exports in the sample is $\$ 507.63$ million, such an increase would equal $\$ 12.74$ million. This means that one additional average immigrant generates an extra $\$ 24,895$ value of exports.

\footnotetext{
7 Concerns about the inclusion of zero observations in the log-transformation of independent variables rather than dependent variables are less frequent in the literature. Nevertheless, they may be valid, as adding a number, such as one, to a variable before log-transformation can bias the results in both cases, because the variance at the left hand side of the distribution of such variable is inflated. We thus attempted excluding zero business migration networks from estimations. Our main results remain valid, although some magnitudes change. However, once again, we are quite confident that our zero business network values are true zero values, and thus we do not wish to exclude them from the analysis. Therefore, alternatively, we also tried a log-level regression specification, which allows preserving the zero values of independent variables. Our key variables of interest - share of business networks and total migration stock have the same sign and significance as in log-log specification. These results are available on request.

These numbers are comparable with those obtained by Head and Ries (1998), who found that an extra migrant in Canada generated $\$ 8,000$ of imports almost two decades earlier. Given that the value of imports in the world has increase by about a half since the 1992, their projection year, while the world stock of migrants has increased by about 20\% (the World Bank, 2010); and given that our coefficient on LIMM IGRANT is also almost twice as high as the one obtained by Heand and Ries (1998), our aggregate result is very similar to theirs. In contrast, our result is almost ten times higher than the one obtained by Felbermayr and Jung (2008), who found that an additional migrant creates about $\$ 2,700$ dollar in additional trade in 2000 . The discrepancy is due to 1) a different coefficient on LIMMIGRANT, which is twice as low in their study; 2) a different average number of migrants per country pair (27000 persons in their sample of OECD receiving countries, versus 5118 persons in our sample), and 3) the fact that our measure of migrant stock is comprised of the active immigrant population, while they use total migrant stock, including inactive and out of the labor force individuals.
} 
However, if the same additional $10 \%$ of immigrants were to be employed all in business network occupations, this would raise the average business share of migrants from 0.137 to 0.216 , a fifty-seven percent increase. Using the coefficient on $\operatorname{Ln}\left(\right.$ share $\left.^{b l}\right)$ reported in Table 3, column 2, such an increase would raise total exports by $31.3 \%$. This is ten times more than a simple increase in the total number of immigrants. Thus, an extra "business" migrant would generate \$310,259 extra value of exports, or over ten times more than an average migrant.

\subsection{Business networks and Trade of Homogeneous and Differentiated Goods}

Table 3, Columns 3 to 11 shows the trade-creating effect of business networks when trade is disaggregated into different categories of goods according to their elasticity of substitution. This disaggregation allows testing a specific implication of the Chaney (2008) model. If migration reduces the fixed costs of doing business with a foreign country and hence the fixed cost of exporting there, this model suggests that highly differentiated goods should benefit more from cost reduction as compared to other goods. The reduction of fixed costs, in fact, would allow entry of more firms into those markets.

We look separately at the effect on imports (columns 3-5), and exports (columns 6-8), continuing to proxy business networks with employed in occupations of Group 1. Alternatively we consider also occupations in Groups 5 and 9 (columns 9-11). Business networks based on occupations in Group 1 have the strongest impact on exports and no significant effect on import. This is in line with the information theory. However, the most significant export effect of business network immigrants is achieved for homogeneous goods. This is in contrast with the theory. The impact of the total number of migrants is intact. Using these coefficients from column 8 , a $10 \%$ increase in the total stock of migrants, ceteris paribus, would raise exports in homogeneous goods by $2,77 \%$. If the same number of extra migrants is employed in business-related occupations, ceteris paribus, exports in homogeneous goods would go up by $51 \%$.

These results are somewhat in disagreement with the theory that business networks should encourage especially trade of differentiated goods as in those cases information barriers may be particularly costly. We will come back to this issue when we consider the specific effect of immigrant-network by education.

\subsection{Business Networks: Occupational or Educational Effect?}

Is it possible that our measure of business networks simply captures the effect of highly educated individuals on trade? Felbermayr and Jung (2009) have argued that highly educated immigrants are those most conducive to trade flows. To distinguish between the effect of the specific business network occupations and the effect of highly educated immigrants we proceed as follows. First, using the information on the number of individuals with different levels of education, we control for the shares of individuals with secondary and with tertiary 
education in addition to the business network share (Table 4 , columns 1-2) ${ }^{9}$. The estimates reveal that once we control for the share of immigrants in business network occupations, the share of highly educated immigrants is not significant any longer. In columns 3-4 of Table 4, we show a variation of the previous approach. Following the specification of Felbermayr and Jung (2009), we include as explanatory variables the stocks of immigrants disaggregated into three education categories: basic schooling, secondary schooling, and tertiary schooling. We also include the share of immigrants in business network occupations. Similarly to these authors, we find a significant trade-creating effect of the highest education group, although no effect on other education groups; we also find a strong effect of the business network shares on exports as well as on imports.

To explore this issue further, we use the occupation and education definitions jointly. We group immigrant workers into business networks and education cells. We include the log of the share of business network immigrants with low, intermediate and high education level (Table 4, columns 5-8). In columns 5-6, the omitted group is the share of all non-business networks. Interestingly, we find that only the number of immigrants who are both in business network occupations and highly-educated has a trade-creation effect beyond the effect of the overall number of immigrants. On the other hand, consistently with the information theory, this group has no effect on imports. Even more interesting is the contrast of the effect of highly educated in business network occupations relative to the effect of poorly educated in non-business network educations (the omitted category, Table 4, columns 7 and 8). Both for imports and exports, only highly educated in business network occupations have a positive and significant effect, while poorly educated in business occupations have insignificant and sometimes negative effects.

Finally, Table 5 analyzes the impact of the immigrant business networks on trade of homogeneous, intermediate and differentiated goods when controlling also for immigrants by schooling (and hence extending the specification of Felbermayr and Jung, 2009, to differentiated trade). Once the stocks of migrants by education level are controlled for, we find that business networks have a positive and significant effect on imports of differentiated goods and on exports of differentiated and homogeneous goods. This is partly consistent with the predictions of Chaney (2008). This implies that controlling for the schooling of immigrants is important to account for their skills and their trade effect, especially when analyzing differentiated goods. It may be the case that highly educated immigrants even in other occupations (e.g. doctors, engineers, professors, scientists) can help generating the kind of networks that induce trade through exposure to their culture, possible contacts, etc. Hence, highly educated stimulate differentiated/intermediate trade. However, even when we control for those, differentiated trade can still benefit from specific business networks.

\footnotetext{
9 Immigrants' education is reported under 4 categories: 1 - no education, completed primary, uncompleted secondary; 2 - completed secondary; 3 - completed tertiary; 99 - unknown. Individuals with unknown education are treated as if they were in category 1.
} 


\subsection{Interactions of Business Networks with Common Factors}

Do business networks of migrants help to create trade between all country-pairs equally? To quantify which type of bilateral relationship may be affected the most we further analyze the interactions of business networks with country-pair factors. Specifically, we look at interactions with common language, common colonial past, common religion, and common legal origin. In Table 6 , these interactions are included one at a time.

The main business network effects on imports and exports are still significant. At the same time, common language, colonial past, and common legal origin reduce the importance of the business networks (although not always in a significant way). This is because if countries already have commonalities, the presence of business networks is less relevant. In these countries, there are fewer cultural barriers to trade to overcome, and the role of business networks as conductors of culture, norms, and common values, is less important. Conversely, in countries with different legal origin, for example, the effect of business networks is more important. These countries differ in the way legal systems are organized. Such differences imply significant variations in the protection of outsider investors' rights, in writing and enforcing contracts, including the ones related to shipment and supply, in formalism of judicial procedures, in settling disputes, or in security of property rights (La Porta et al., 2008). Bridging these differences with information acquired through the business networks, and the experience of individuals, is thus especially relevant for stimulating trade.

Common religion seems to be the only "cultural variable" that works to strengthen the effects of business networks. This may be because religion would not establish ex-ante trade ties, but once immigrants establish their networks, religion may reinforce them. This may be consistent with historical examples from some religions which were functional to establishing trade relations between some countries ${ }^{10}$. It is also in line with the idea that certain religions can be more conducive than others for forming international trade networks (Lewer and Van den Berg, 2007). The fact of belonging to the same religion may create additional reputation mechanisms that are vital for coordinating and reinforcing expectations between trading partners (Greif, 1989; 1993).

\section{CONCLUSIONS}

In this paper, we have proposed a new estimation of migration networks' impact on trade based on new, more precise measures of migration networks. We have shown that, controlling for the overall size of bilateral stock of migrants, individuals employed directly in business network occupations produce large and significant effects on trade, and especially on exports from their home countries. They generate over ten times the value of trade than average migrants. Moreover, this occupation-based measure works better than a schooling-based one

\footnotetext{
${ }^{10}$ Cowen (1997) reproduced in Felbermayr, Jung, and Toubal (2011), says: “... the Spanish Jews were indispensable for international commerce in the Middle Ages. [...] Lebanese Christians developed trade between various parts of the Ottoman empire" (p.170).
} 
in explaining bilateral trade. When controlling for the bilateral stock of migrants, the share of educated individuals does not augment trade, while the share of business-related migrants does. When controlling for schooling, we also find a particularly large effect of business networks on trade in differentiated goods. We also find significant effects of business networks on trade in homogeneous (easily substitutable) goods.

Our findings suggest that the business network effect is especially important for culturally distant countries, such as countries with different legal origin. In such setting, business networks are particularly effective in fulfilling their function of information sharing, of helping overcome problems related to differences in legal enforcement, of providing legal advice and experience. As the international legal systems remain weak, and trade disputes are settled mainly in national courts using national legislations, migrant business networks play the key role of informational intermediaries.

If receiving countries are to expand trade-related benefits from migration, clearly, promoting entrepreneurship and facilitating establishment of businesses by migrants can be valuable. For example, policies such as the European blue card, which favors the free movement and work of highly-skilled individuals in highly-paid positions (business network migrants among them) and provisions that allow immigration of any person who invests a certain amount and hires local workers should be expanded. 


\section{REFERENCES}

Anderson, J., E., Wincoop, V., 2003. Gravity with Gravitas: A Solution to the Border Puzzle. American Economic Review, 93(1), 170-192.

Bandyopadhyay, S., C. C., Coughlin, H. J. Wall, 2008. Ethnic Networks and US Exports. Review of International Economics, 16 (1), 199-213.

Baldwin, R., Taglioni, D., 2006. Gravity for Dummies and Dummies for Gravity Equations, NBER Working Paper No. 12516.

Broda, C., Weinstein, D., 2006. Globalization and the Gains from Variety. Quarterly Journal of Economics, 121(2), 541-585.

CEPII Gravity Dataset. Available at: http://www.cepii.fr/anglaisgraph/bdd/gravity.htm

Chaney, T., 2008. Distorted Gravity - Heterogeneous Firms, Market Structure and the Geography of International Trade. American Economic Review, 98(4), 1707-1721.

Chiswick, B, and W.P.Miller, 2009. The International Transferability of Immigrants' Human Capital Skills. Economics of Education Review, 28(2), pp. 152-169.

Combes, P.P., Lafourcade, M., Mayer,T., 2005. The Trade-Creating Effects of Business and Social Networks: Evidence from France. Journal of International Economics, 66 (2): $1-29$.

Dumont, J.-C., Spielvogel, G., Widmaier, S., 2010. International Migrants in Developed, Emerging and Developing Countries: An Extended Profile. OECD Social, Employment and Migration Working Papers No.114. Available at: www.oecd.org/els/workingpapers. Accessed: March 2011.

Dunlevy, J., 2006. The Influence of Corruption and Language on the Pro-trade Effect of Immigrants: Evidence from the American States. The Review of Economics and Statistics, 88 (1), 182-186.

Dunlevy, J., Hutchinson, W., 1999. The Impact of Immigration on American Import Trade in the Late Nineteenth and Twentieth Centuries. Journal of Economic History, 59, $1043-$ 62.

Feenstra, R.C., 2004. Advanced International Trade: Theory and Evidence. Princeton: Princeton University Press. 
Felbermayr, G. J., Jung, B., 2009. The Pro-Trade Effect of the Brain Drain: Sorting out Confounding Factors, Economics Letters, 104(2), 72-75.

Felbermayr, G. J., Kohler, W., 2006. Exploring the Intensive and Extensive Margins of World Trade. Review of World Economics, 142(4), 642-674.

Felbermayr, G. J., Jung B., Toubal, F., 2011. Ethnic Networks, Information and International Trade : Revisiting the Evidence. Annales d'Economie et de Statistique. 97/98 (4).

Felbermayr, G. J., Toubal, F., Revisiting the Trade-Migration Nexus: Evidence from New OECD data. World Development - forthcoming.

Gaulier, G., Zignago, S., 2010. BACI: International Trade Database at the Product-level. The 1994-2007 Version. Working Paper 2010-23. CEPII Research Center.

Girma, S., Yu, Z., 2002. The Link between Immigration and Trade: Evidence from the United Kingdom. Weltwirtschaftliches Archiv, 138, 115-130.

Gould, D., 1994. Immigrant Links to the Home Country: Empirical Implications for U.S. Bilateral Trade Flows. The Review of Economics and Statistics, 76(2), 302-316.

Greif, A., 1989. Reputation and Coalitions in Medieval Trade: Evidence on the Maghribi Traders. The Journal of Economic History, 49(4), 857-882.

Greif, A., 1993. Contract Enforceability and Economic Institutions in Early Trade: The Maghribi Traders' Coalition. The American Economic Review, 83(3), 525-548.

Head, K., Mayer, T., Ries, J., 2010. The Erosion of Colonial Trade Linkages after Independence. Journal of International Economics, 81(1), 1-14.

Head, K., Ries, J., 1998. Immigration and Trade Creation: Econometric Evidence from Canada. Canadian Journal of Economics, 31(1), 47-62.

Martin, W., Pham, C., 2009. Estimating the Gravity Model When Zero Trade Flows are Frequent. World Bank manuscript.

La Porta, R., Lopez-de-Silanes F., Shleifer A., 2008. The Economic Consequences of Legal Origins. Journal of Economic Literature, 46 (2), 285-332.

Lewer, J. J., Van den Berg, H., 2007. Religion and International Trade. American Journal of Economics and Sociology, 66(4), 765-794.

OECD, 2010. DIOC-E Database (Paris: OECD). Available at: http://www.oecd.org/document/33/0,3746,en_2649_37415_46561249_1_1_1_37415,0 0.html . Accessed: October 2010. 
Peri, G., Requena, F., 2010. The Trade Creation Effect of Immigrants: Evidence from the Remarkable Case of Spain. Canadian Journal of Economics, 49, 1433-1459.

Rauch, J. E., 1999. Networks versus Markets in International Trade. Journal of International Economics, 48, 116-130.

Rauch, J. E., 2001. Business and Social Networks in International Trade. Journal of Economic Literature, 39, 1177-1203.

Rauch, J. E. and Trindale, V., 2002. Ethnic Chinese Networks in International Trade. The Review of Economics and Statistics, 84(1), 116-130.

Santos Silva J., Tenreyro, S., 2006. The Log of Gravity. The Review of Economics and Statistics, 88(4), 641-658.

Wagner, D., Head, K., Ries, J., 2002. Immigration and the Trade of Provinces. Scottish Journal of Political Economy, 49, 507-25.

World Bank, 2010. International Migrant Stock, Total. Database, available at: http://data.worldbank.org/indicator/SM.POP.TOTL/countries?display=default. 
Table 1: Summary statistics of the shares of foreign-born, relevance of business networks and openness to trade, OECD countries, circa 2000

\begin{tabular}{|c|c|c|c|c|c|}
\hline Country ISO Code & $\begin{array}{c}\text { Share of } \\
\text { immigrants } \\
\text { in } \\
\text { population }\end{array}$ & $\begin{array}{l}\text { Share Occ. } 1 \\
\text { among } \\
\text { immigrants }\end{array}$ & $\begin{array}{l}\text { Share Occ.5 } \\
\text { among } \\
\text { immigrants }\end{array}$ & $\begin{array}{c}\text { Share Occ. } 9 \\
\text { among } \\
\text { immigrants }\end{array}$ & $\begin{array}{l}\text { Export+import as } \\
\text { share of GDP }\end{array}$ \\
\hline & (1) & (2) & (3) & (4) & (5) \\
\hline Australia & 0,245 & 0,107 & 0,126 & 0,146 & 0,373 \\
\hline Austria & 0,138 & 0,066 & 0,138 & 0,281 & 0,807 \\
\hline Belgium & 0,095 & 0,149 & 0,114 & 0,123 & 1,687 \\
\hline Canada & 0,206 & 0,117 & 0,143 & 0,088 & 0,803 \\
\hline Switzerland & 0,253 & 0,060 & 0,111 & 0,417 & 0,869 \\
\hline Chile & 0,017 & 0,129 & 0,111 & 0,253 & 0,552 \\
\hline Czech Rep., the & 0,040 & 0,086 & 0,141 & 0,144 & 1,283 \\
\hline Germany & 0,118 & 0,015 & 0,149 & 0,199 & 0,616 \\
\hline Denmark & 0,058 & 0,013 & 0,122 & 0,434 & 0,652 \\
\hline Spain & 0,068 & 0,072 & 0,168 & 0,273 & 0,504 \\
\hline Estonia & 0,195 & 0,102 & 0,103 & 0,172 & 2,166 \\
\hline Finland & 0,022 & 0,022 & 0,184 & 0,197 & 0,762 \\
\hline France & 0,092 & 0,100 & 0,106 & 0,109 & 0,479 \\
\hline Great Britain & 0,088 & 0,170 & 0,163 & 0,103 & 0,469 \\
\hline Hungary & 0,029 & 0,105 & 0,161 & 0,057 & 1,412 \\
\hline Ireland & 0,121 & 0,159 & 0,137 & 0,119 & 1,368 \\
\hline Israel & 0,373 & 0,062 & 0,166 & 0,121 & 0,578 \\
\hline Italy & 0,050 & 0,098 & 0,136 & 0,223 & 0,466 \\
\hline Luxembourg & 0,426 & 0,068 & 0,088 & 0,251 & 0,015 \\
\hline Mexico & 0,004 & 0,147 & 0,149 & 0,186 & 0,661 \\
\hline Netherlands, the & 0,098 & 0,085 & 0,114 & 0,175 & 1,188 \\
\hline Norway & 0,056 & 0,071 & 0,217 & 0,119 & 0,583 \\
\hline New Zealand & 0,197 & 0,131 & 0,134 & 0,134 & 0,589 \\
\hline Poland & 0,008 & 0,104 & 0,099 & 0,080 & 0,500 \\
\hline Portugal & 0,085 & 0,075 & 0,144 & 0,148 & 0,661 \\
\hline Slovenia & 0,026 & 0,092 & 0,093 & 0,184 & 1,478 \\
\hline Average & 0,119 & 0,090 & 0,138 & 0,184 & 0,822 \\
\hline
\end{tabular}


Table 2. The Effect of Business Networks on Trade: Basic Specifications

\begin{tabular}{|c|c|c|c|c|c|c|c|c|c|c|c|c|c|c|}
\hline & \multicolumn{10}{|c|}{ OLS } & \multicolumn{2}{|c|}{ PMLE } & \multicolumn{2}{|c|}{ Tobit } \\
\hline & $\begin{array}{l}\text { LImports } \\
\text { (1) }\end{array}$ & $\begin{array}{l}\text { LExports } \\
\text { (2) }\end{array}$ & $\begin{array}{l}\text { LImports } \\
\text { (3) }\end{array}$ & $\begin{array}{l}\text { LExports } \\
\text { (4) }\end{array}$ & $\begin{array}{l}\text { LImports } \\
(5)\end{array}$ & $\begin{array}{c}\text { LExports } \\
\text { (6) }\end{array}$ & $\begin{array}{c}\text { LImports } \\
\text { (7) }\end{array}$ & $\begin{array}{l}\text { LExports } \\
\text { (8) }\end{array}$ & $\begin{array}{c}\text { LImports } \\
(9)\end{array}$ & $\begin{array}{l}\text { LExports } \\
\text { (10) }\end{array}$ & $\begin{array}{l}\text { Imports } \\
\text { (11) }\end{array}$ & $\begin{array}{c}\text { Exports } \\
\text { (12) }\end{array}$ & $\begin{array}{l}\text { LImports } \\
\text { (13) }\end{array}$ & $\begin{array}{l}\text { LExports } \\
\text { (14) }\end{array}$ \\
\hline \multirow[t]{2}{*}{$\operatorname{Ln}\left(\right.$ total $\left.^{\mathrm{bl}}\right)$} & $0.259 * *$ & $0.231 * *$ & & & & & & & & & & & & \\
\hline & $(0.0192)$ & $(0.0153)$ & & & & & & & & & & & & \\
\hline $\operatorname{Ln}\left(\right.$ share $\left.^{b l}\right)$ & & & $\begin{array}{l}0.643 * \\
(0.307)\end{array}$ & $\begin{array}{l}0.484 * \\
(0.225)\end{array}$ & & & $\begin{array}{l}0.679^{*} \\
(0.306)\end{array}$ & $\begin{array}{l}0.526^{*} \\
(0.227)\end{array}$ & & & $\begin{array}{l}1.037 * * \\
(0.359)\end{array}$ & $\begin{array}{l}0.460 * \\
(0.250)\end{array}$ & $\begin{array}{l}0.651^{*} \\
(0.253)\end{array}$ & $\begin{array}{c}0.614 * * \\
(0.221)\end{array}$ \\
\hline $\operatorname{Ln}\left(\right.$ share $\left.^{\mathrm{b} 59}\right)$ & & & & & $\begin{array}{c}0.166 \\
(0.277)\end{array}$ & $\begin{array}{c}0.228 \\
(0.192)\end{array}$ & $\begin{array}{c}0.246 \\
(0.277)\end{array}$ & $\begin{array}{c}0.289 \\
(0.193)\end{array}$ & & & & & & \\
\hline $\operatorname{Ln}\left(\right.$ share $\left.^{\mathrm{nb}}\right)$ & & & & & & & & & $\begin{array}{c}-0.545 \\
(0.394)\end{array}$ & $\begin{array}{c}-0.282 \\
(0.268)\end{array}$ & & & & \\
\hline \multirow[t]{2}{*}{ Ln(IMMIGRANT) } & & & $0.273 * *$ & $0.267 * *$ & $0.268 * *$ & $0.262 * *$ & $0.270 * *$ & $0.264 * *$ & $0.272 * *$ & $0.266^{* *}$ & $0.172 * *$ & $0.160 * *$ & $0.291 * *$ & $0.288 * *$ \\
\hline & & & $(0.018)$ & $(0.015)$ & $(0.018)$ & $(0.015)$ & $(0.018)$ & $(0.015)$ & $(0.018)$ & $(0.015)$ & $(0.016)$ & $(0.015)$ & $(0.018)$ & $(0.016)$ \\
\hline \multirow[t]{2}{*}{$\operatorname{Ln}\left(y^{*} y\right)$} & 0.130 & 0.316 & 0.130 & 0.314 & 0.119 & 0.305 & 0.132 & 0.314 & 0.125 & 0.309 & $0.510 *$ & $0.612 * *$ & -0.038 & $0.436^{*}$ \\
\hline & $(0.324)$ & $(0.250)$ & $(0.322)$ & $(0.249)$ & $(0.322)$ & $(0.250)$ & $(0.322)$ & $(0.249)$ & $(0.322)$ & $(0.249)$ & $(0.272)$ & $(0.262)$ & $(0.269)$ & $(0.232)$ \\
\hline \multirow[t]{2}{*}{$\operatorname{Ln}($ distance $)$} & $-1.231 * *$ & $-1.378 * *$ & $-1.152 * *$ & $-1.278 * *$ & $-1.152 * *$ & $-1.281 * *$ & $-1.154 * *$ & $-1.281 * *$ & $-1.152 * *$ & $-1.279 * *$ & $-0.791 * *$ & $-0.823 * *$ & $-1.161 * *$ & $-1.305^{* *}$ \\
\hline & $(0.050)$ & $(0.043)$ & $(0.051)$ & $(0.043)$ & $(0.051)$ & $(0.043)$ & $(0.051)$ & $(0.043)$ & $(0.051)$ & $(0.043)$ & $(0.044)$ & $(0.049)$ & $(0.049)$ & $(0.048)$ \\
\hline \multirow[t]{2}{*}{ Contiguity } & 0.085 & $0.229^{*}$ & 0.016 & 0.133 & 0.004 & 0.123 & 0.018 & 0.135 & 0.007 & 0.125 & $0.207 * *$ & $0.248 * *$ & $-0.363^{*}$ & -0.250 \\
\hline & $(0.144)$ & $(0.124)$ & $(0.144)$ & $(0.121)$ & $(0.144)$ & $(0.121)$ & $(0.144)$ & $(0.120)$ & $(0.144)$ & $(0.121)$ & $(0.054)$ & $(0.061)$ & $(0.172)$ & $(0.164)$ \\
\hline \multirow[t]{2}{*}{ Comm language } & $0.320 * *$ & $0.226^{* *}$ & $0.302 * *$ & $0.187^{*}$ & $0.316^{* *}$ & $0.198^{*}$ & $0.305 * *$ & $0.190 *$ & $0.309 * *$ & $0.193 *$ & 0.083 & 0.011 & $0.418 * *$ & $0.395 * *$ \\
\hline & $(0.101)$ & $(0.079)$ & $(0.100)$ & $(0.078)$ & $(0.100)$ & $(0.078)$ & $(0.101)$ & $(0.078)$ & $(0.100)$ & $(0.078)$ & $(0.061)$ & $(0.073)$ & $(0.099)$ & $(0.086)$ \\
\hline \multirow[t]{2}{*}{ Colony } & $0.646^{* *}$ & $0.617 * *$ & $0.598 * *$ & $0.516^{* *}$ & $0.606^{* *}$ & $0.526^{* *}$ & $0.603 * *$ & $0.522 * *$ & $0.599 * *$ & $0.518^{* *}$ & $0.187^{*}$ & 0.114 & $0.510^{* *}$ & $0.390 * *$ \\
\hline & $(0.133)$ & $(0.110)$ & $(0.132)$ & $(0.106)$ & $(0.132)$ & $(0.106)$ & $(0.131)$ & $(0.106)$ & $(0.132)$ & $(0.106)$ & $(0.083)$ & $(0.097)$ & $(0.151)$ & $(0.129)$ \\
\hline \multirow[t]{2}{*}{ RTA } & -0.0883 & $-0.184 * *$ & -0.0654 & $-0.164 * *$ & -0.0668 & $-0.165 * *$ & -0.0640 & $-0.162 * *$ & -0.0688 & $-0.167 * *$ & $0.449 * *$ & $0.466^{* *}$ & -0.144 & $-0.365^{* *}$ \\
\hline & $(0.0852)$ & $(0.0747)$ & $(0.0850)$ & $(0.0737)$ & $(0.0851)$ & $(0.0737)$ & $(0.0850)$ & $(0.0738)$ & $(0.0850)$ & $(0.0737)$ & $(0.075)$ & $(0.079)$ & $(0.088)$ & $(0.086)$ \\
\hline Observations & 4,806 & 4,923 & 4,806 & 4,923 & 4,806 & 4,923 & 4,806 & 4,923 & 4,806 & 4,923 & 5230 & 5230 & 5230 & 5230 \\
\hline R-squared & 0.795 & 0.833 & 0.797 & 0.837 & 0.796 & 0.836 & 0.797 & 0.837 & 0.796 & 0.836 & & & 0.295 & 0.314 \\
\hline
\end{tabular}

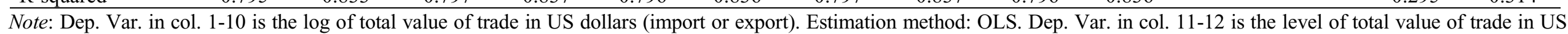

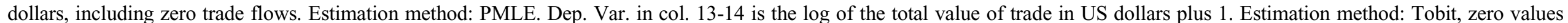

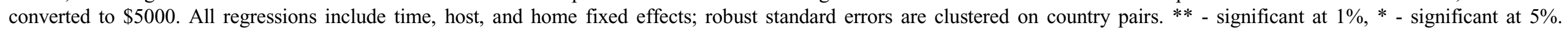


Table 3. Business Networks and Trade in Homogeneous and Heterogeneous Goods

\begin{tabular}{|c|c|c|c|c|c|c|c|c|c|c|c|}
\hline & \multirow{2}{*}{$\begin{array}{c}\text { Imports } \\
\text { Total } \\
(1)\end{array}$} & \multirow{2}{*}{$\begin{array}{c}\text { Exports } \\
\text { Total } \\
(2)\end{array}$} & \multicolumn{3}{|c|}{ Imports } & \multicolumn{6}{|c|}{ Exports } \\
\hline & & & $\begin{array}{l}\text { Diff } \\
(3)\end{array}$ & $\begin{array}{c}\text { Medium } \\
\text { (4) }\end{array}$ & $\begin{array}{c}\text { Homo } \\
(5)\end{array}$ & $\begin{array}{l}\text { Diff } \\
(6)\end{array}$ & $\begin{array}{c}\text { Medium } \\
\text { (7) }\end{array}$ & $\begin{array}{c}\text { Homo } \\
(8)\end{array}$ & $\begin{array}{c}\text { Diff } \\
(9)\end{array}$ & $\begin{array}{c}\text { Medium } \\
\text { (10) }\end{array}$ & $\begin{array}{c}\text { Homo } \\
(11)\end{array}$ \\
\hline $\operatorname{Ln}\left(\right.$ share $\left.^{b 1}\right)$ & $\begin{array}{c}0.012 \\
(0.310)\end{array}$ & $\begin{array}{c}0.549 * \\
(0.245)\end{array}$ & $\begin{array}{c}0.195 \\
(0.288)\end{array}$ & $\begin{array}{c}0.470 \\
(0.280)\end{array}$ & $\begin{array}{c}0.359 \\
(0.315)\end{array}$ & $\begin{array}{c}0.234 \\
(0.262)\end{array}$ & $\begin{array}{c}0.338 \\
(0.256)\end{array}$ & $\begin{array}{c}0.876 * * \\
(0.288)\end{array}$ & $\begin{array}{c}0.252 \\
(0.263)\end{array}$ & $\begin{array}{c}0.393 \\
(0.258)\end{array}$ & $\begin{array}{c}0.892 * * \\
(0.290)\end{array}$ \\
\hline $\operatorname{Ln}\left(\right.$ share $\left.^{\mathrm{b} 59}\right)$ & & & & & & & & & $\begin{array}{c}0.131 \\
(0.235)\end{array}$ & $\begin{array}{c}0.401 \\
(0.216)\end{array}$ & $\begin{array}{c}0.113 \\
(0.238)\end{array}$ \\
\hline Ln(IMMIGRANT) & $\begin{array}{c}0.261 * * \\
(0.018)\end{array}$ & $\begin{array}{c}0.251 * * \\
(0.016)\end{array}$ & $\begin{array}{c}0.257 * * \\
(0.019)\end{array}$ & $\begin{array}{c}0.259 * * \\
(0.018)\end{array}$ & $\begin{array}{c}0.259 * * \\
(0.020)\end{array}$ & $\begin{array}{c}0.266 * * \\
(0.016)\end{array}$ & $\begin{array}{c}0.285^{* *} \\
(0.016)\end{array}$ & $\begin{array}{c}0.277 * * \\
(0.017)\end{array}$ & $\begin{array}{c}0.265 * * \\
(0.016)\end{array}$ & $\begin{array}{c}0.281 * * \\
(0.016)\end{array}$ & $\begin{array}{c}0.276^{* *} \\
(0.017)\end{array}$ \\
\hline $\operatorname{Ln}(y * y)$ & $\begin{array}{c}0.304 \\
(0.304)\end{array}$ & $\begin{array}{c}0.616^{*} \\
(0.370)\end{array}$ & $\begin{array}{c}0.374 \\
(0.294)\end{array}$ & $\begin{array}{c}0.694 * * \\
(0.347)\end{array}$ & $\begin{array}{l}-0.160 \\
(0.303)\end{array}$ & $\begin{array}{c}1.193 * * \\
(0.257)\end{array}$ & $\begin{array}{c}1.166^{* *} \\
(0.269)\end{array}$ & $\begin{array}{c}0.866^{* *} \\
(0.279)\end{array}$ & $\begin{array}{c}1.193 * * \\
(0.257)\end{array}$ & $\begin{array}{c}1.164 * * \\
(0.270)\end{array}$ & $\begin{array}{c}0.865^{* *} \\
(0.279)\end{array}$ \\
\hline $\operatorname{Ln}($ distance $)$ & $\begin{array}{c}-1.152 * \\
(0.052)\end{array}$ & $\begin{array}{c}-1.311^{* *} \\
(0.048)\end{array}$ & $\begin{array}{c}-1.148^{* *} \\
(0.051)\end{array}$ & $\begin{array}{c}-1.116^{* *} \\
(0.049)\end{array}$ & $\begin{array}{c}-1.302 * * \\
(0.058)\end{array}$ & $\begin{array}{c}-1.331 * * \\
(0.045)\end{array}$ & $\begin{array}{c}-1.337 * * \\
(0.044)\end{array}$ & $\begin{array}{c}-1.401 * * \\
(0.048)\end{array}$ & $\begin{array}{c}-1.332 * * \\
(0.045)\end{array}$ & $\begin{array}{c}-1.340 * * \\
(0.045)\end{array}$ & $\begin{array}{r}-1.401 * * \\
(0.048)\end{array}$ \\
\hline Contiguity & $\begin{array}{c}0.005 \\
(0.138)\end{array}$ & $\begin{array}{c}0.079 \\
(0.127)\end{array}$ & $\begin{array}{l}-0.022 \\
(0.138)\end{array}$ & $\begin{array}{c}0.020 \\
(0.132)\end{array}$ & $\begin{array}{c}0.058 \\
(0.140)\end{array}$ & $\begin{array}{l}-0.135 \\
(0.127)\end{array}$ & $\begin{array}{l}-0.265 * \\
(0.125)\end{array}$ & $\begin{array}{l}-0.032 \\
(0.131)\end{array}$ & $\begin{array}{l}-0.134 \\
(0.127)\end{array}$ & $\begin{array}{c}-0.262 * \\
(0.125)\end{array}$ & $\begin{array}{l}-0.031 \\
(0.131)\end{array}$ \\
\hline Comm language & $\begin{array}{c}0.345^{* *} \\
(0.097)\end{array}$ & $\begin{array}{c}0.358 * * \\
(0.080)\end{array}$ & $\begin{array}{c}0.355^{* *} \\
(0.103)\end{array}$ & $\begin{array}{c}0.291 * * \\
(0.096)\end{array}$ & $\begin{array}{c}0.340^{* *} \\
(0.111)\end{array}$ & $\begin{array}{c}0.309 * * \\
(0.083)\end{array}$ & $\begin{array}{c}0.285^{* *} \\
(0.081)\end{array}$ & $\begin{array}{l}0.184^{*} \\
(0.089)\end{array}$ & $\begin{array}{c}0.311^{* *} \\
(0.083)\end{array}$ & $\begin{array}{c}0.291 * * \\
(0.081)\end{array}$ & $\begin{array}{c}0.185^{* *} \\
(0.089)\end{array}$ \\
\hline Colony & $\begin{array}{c}0.491 * * \\
(0.130)\end{array}$ & $\begin{array}{c}0.447 * * \\
(0.106)\end{array}$ & $\begin{array}{c}0.675^{* *} \\
(0.139)\end{array}$ & $\begin{array}{c}0.523 * * \\
(0.126)\end{array}$ & $\begin{array}{c}0.445^{* *} \\
(0.126)\end{array}$ & $\begin{array}{c}0.593 * * \\
(0.113)\end{array}$ & $\begin{array}{c}0.560 * * \\
(0.112)\end{array}$ & $\begin{array}{c}0.441^{* *} \\
(0.115)\end{array}$ & $\begin{array}{c}0.595 * * \\
(0.113)\end{array}$ & $\begin{array}{c}0.568^{* *} \\
(0.112)\end{array}$ & $\begin{array}{c}0.443 * * \\
(0.115)\end{array}$ \\
\hline RTA & $\begin{array}{c}0.076 \\
(0.086)\end{array}$ & $\begin{array}{l}-0.115 \\
(0.081)\end{array}$ & $\begin{array}{l}0.0592 \\
(0.088)\end{array}$ & $\begin{array}{c}0.098 \\
(0.083)\end{array}$ & $\begin{array}{c}0.255^{* *} \\
(0.092)\end{array}$ & $\begin{array}{c}0.039 \\
(0.078)\end{array}$ & $\begin{array}{c}0.038 \\
(0.074)\end{array}$ & $\begin{array}{c}0.119 \\
(0.082)\end{array}$ & $\begin{array}{l}0.0405 \\
(0.078)\end{array}$ & $\begin{array}{c}0.041 \\
(0.074)\end{array}$ & $\begin{array}{c}0.120 \\
(0.082)\end{array}$ \\
\hline Observations & 4,757 & 4,874 & 4,317 & 4,390 & 4,324 & 4,646 & 4,649 & 4,610 & 4,646 & 4,649 & 4,610 \\
\hline R-squared & 0.769 & 0.746 & 0.832 & 0.831 & 0.792 & 0.825 & 0.826 & 0.798 & 0.825 & 0.826 & 0.798 \\
\hline
\end{tabular}

Note: Dependent variable: the logarithm of the value of trade in US dollars (import or export), in $\mathrm{t}+2$. Estimation method: OLS. All regressions include the full set of time, host, and home fixed effects; robust standard errors are clustered on country pairs. ** - significant at $1 \%, *$ - significant at $5 \%$. 
Table 4. Business Networks or Education?

\begin{tabular}{|c|c|c|c|c|c|c|c|c|}
\hline & LImports (1) & LExports (2) & LImports (3) & LExports (4) & LImports (5) & LExports (6) & LImports (7) & LExports (8) \\
\hline \multirow[t]{2}{*}{$\operatorname{Ln}\left(\right.$ share $\left.^{\mathrm{bl}}\right)$} & 0.606 & $0.811 *$ & $0.911 *$ & $0.950 *$ & & & & \\
\hline & $(0.393)$ & $(0.348)$ & $(0.460)$ & $(0.477)$ & & & & \\
\hline \multirow{2}{*}{$\operatorname{Ln}\left(\right.$ share $\left.^{\text {edu2 }}\right)$} & 0.0881 & 0.0184 & & & & & & \\
\hline & $(0.380)$ & $(0.326)$ & & & & & & \\
\hline \multirow[t]{2}{*}{$\operatorname{Ln}\left(\right.$ share $\left.^{\text {edu3 }}\right)$} & 0.118 & 0.342 & & & & & & \\
\hline & $(0.334)$ & $(0.276)$ & & & & & & \\
\hline \multirow[t]{2}{*}{$\operatorname{Ln}\left(\right.$ total $\left.^{\text {edul }}\right)$} & & & 0.042 & 0.032 & & & & \\
\hline & & & $(0.039)$ & $(0.035)$ & & & & \\
\hline \multirow[t]{2}{*}{ Ln( total $\left.^{\text {edu2 }}\right)$} & & & 0.079 & 0.028 & & & & \\
\hline & & & $(0.060)$ & $(0.051)$ & & & & \\
\hline \multirow[t]{2}{*}{$\operatorname{Ln}\left(\right.$ total $\left.^{\text {edu3 }}\right)$} & & & $0.121 *$ & $0.210^{* *}$ & & & & \\
\hline & & & $(0.052)$ & $(0.042)$ & & & & \\
\hline \multirow[t]{2}{*}{$\operatorname{Ln}\left(\right.$ share $\left.^{\text {b1_edu1 }}\right)$} & & & & & -1.734 & -1.000 & -1.095 & -1.535 \\
\hline & & & & & $(0.957)$ & $(0.876)$ & $(1.176)$ & $(1.351)$ \\
\hline \multirow[t]{2}{*}{$\operatorname{Ln}\left(\right.$ share $\left.^{\text {b1_edu2 }}\right)$} & & & & & -0.357 & 0.754 & -0.280 & 0.553 \\
\hline & & & & & $(0.562)$ & $(0.425)$ & $(0.629)$ & $(0.702)$ \\
\hline \multirow[t]{2}{*}{$\operatorname{Ln}\left(\right.$ share $\left.^{\text {b1_edu3 }}\right)$} & & & & & 0.309 & $0.701 *$ & $1.455 * *$ & $1.429 * *$ \\
\hline & & & & & $(0.404)$ & $(0.303)$ & $(0.504)$ & $(0.451)$ \\
\hline \multirow[t]{2}{*}{$\operatorname{Ln}\left(\right.$ share $\left.^{\text {nb_edu2 }}\right)$} & & & & & & & 0.316 & 0.0158 \\
\hline & & & & & & & $(0.392)$ & $(0.329)$ \\
\hline \multirow[t]{2}{*}{$\operatorname{Ln}\left(\right.$ share $\left.^{\text {nb_edu3 }}\right)$} & & & & & & & -0.0574 & 0.113 \\
\hline & & & & & & & $(0.336)$ & $(0.284)$ \\
\hline \multirow[t]{2}{*}{ Ln(IMMIGRANT) } & $0.256 * *$ & $0.267 * *$ & & & $0.265 * *$ & $0.255 * *$ & $0.260 * *$ & $0.269 * *$ \\
\hline & $(0.022)$ & $(0.018)$ & & & $(0.019)$ & $(0.016)$ & $(0.022)$ & $(0.018)$ \\
\hline Observations & 3,976 & 4,023 & 3,444 & 3,479 & 4,752 & 4,870 & 3,976 & 4,023 \\
\hline R-squared & 0.808 & 0.825 & 0.819 & 0.835 & 0.800 & 0.826 & 0.808 & 0.825 \\
\hline
\end{tabular}

Note: Dependent variable: the logarithm of the total value of trade in US dollars (import or export), in t+2. Estimation method: OLS. All regressions include the full set of time, host, and home fixed effects, as well as distance, contiguity, common language, colonial past, and RTA controls. Robust standard errors are clustered on country pairs. $* *$ - significant at $1 \%, *$ - significant at $5 \%$. 
Table 5. Business Networks or Education: Trade in Differentiated and Homogeneous Goods

\begin{tabular}{|c|c|c|c|c|c|c|}
\hline & \multicolumn{3}{|c|}{ Imports } & \multicolumn{3}{|c|}{ Exports } \\
\hline & $\begin{array}{l}\text { Diff } \\
(1)\end{array}$ & $\begin{array}{l}\text { Medium } \\
\text { (2) }\end{array}$ & $\begin{array}{l}\text { Homo } \\
\text { (3) }\end{array}$ & $\begin{array}{l}\text { Diff } \\
\text { (4) }\end{array}$ & $\begin{array}{l}\text { Medium } \\
\text { (5) }\end{array}$ & $\begin{array}{l}\text { Homo } \\
(6)\end{array}$ \\
\hline $\operatorname{Ln}\left(\right.$ share $\left.^{\mathrm{b} 1}\right)$ & $\begin{array}{l}1.123^{*} \\
(0.468)\end{array}$ & $\begin{array}{c}0.814 \\
(0.417)\end{array}$ & $\begin{array}{c}0.631 \\
(0.482)\end{array}$ & $\begin{array}{l}0.865^{*} \\
(0.440)\end{array}$ & $\begin{array}{c}0.035 \\
(0.483)\end{array}$ & $\begin{array}{l}1.546^{* *} \\
(0.518)\end{array}$ \\
\hline $\operatorname{Ln}\left(\right.$ total $\left.^{\text {edu1 }}\right)$ & $\begin{array}{c}0.041 \\
(0.037)\end{array}$ & $\begin{array}{l}-0.010 \\
(0.037)\end{array}$ & $\begin{array}{c}0.041 \\
(0.041)\end{array}$ & $\begin{array}{l}0.082^{*} \\
(0.036)\end{array}$ & $\begin{array}{l}-0.003 \\
(0.037)\end{array}$ & $\begin{array}{c}0.042 \\
(0.039)\end{array}$ \\
\hline $\operatorname{Ln}\left(\right.$ total $\left.^{\text {edu2 }}\right)$ & $\begin{array}{l}0.118^{*} \\
(0.058)\end{array}$ & $\begin{array}{c}0.239 * * \\
(0.055)\end{array}$ & $\begin{array}{c}0.101 \\
(0.062)\end{array}$ & $\begin{array}{l}-0.053 \\
(0.056)\end{array}$ & $\begin{array}{l}-0.004 \\
(0.055)\end{array}$ & $\begin{array}{c}0.073 \\
(0.059)\end{array}$ \\
\hline $\operatorname{Ln}\left(\right.$ total $\left.^{\text {edu3 }}\right)$ & $\begin{array}{l}0.113^{*} \\
(0.052) \\
\end{array}$ & $\begin{array}{c}0.036 \\
(0.051) \\
\end{array}$ & $\begin{array}{l}0.112^{*} \\
(0.053) \\
\end{array}$ & $\begin{array}{c}0.272 * * \\
(0.046)\end{array}$ & $\begin{array}{c}0.324 * * \\
(0.044)\end{array}$ & $\begin{array}{r}0.187 * * \\
(0.048) \\
\end{array}$ \\
\hline Observations & 3,259 & 3,282 & 3,255 & 3,386 & 3,397 & 3,387 \\
\hline R-squared & 0.841 & 0.847 & 0.808 & 0.843 & 0.836 & 0.809 \\
\hline
\end{tabular}

Note: Dependent variable: the logarithm of the value of trade in US dollars, in t+2. Estimation method: OLS. All regressions include the full set of time, host, and home fixed effects, as well as distance, contiguity, common language, colonial past, and RTA controls. Robust standard errors are clustered on country pairs. ** - significant at $1 \%, *$ - significant at $5 \%$. 
Table 6. Interactions of Business Networks with Common Factors

\begin{tabular}{|c|c|c|c|c|c|c|c|c|}
\hline & \multicolumn{2}{|c|}{ LImports LExports } & \multicolumn{2}{|c|}{ LImports LExports } & LImports & LExports & \multicolumn{2}{|c|}{ LImports LExports } \\
\hline & \multicolumn{2}{|c|}{ Language } & \multicolumn{2}{|c|}{ Colony } & \multicolumn{2}{|c|}{ Religion } & \multicolumn{2}{|c|}{ Legal origin } \\
\hline & (1) & (2) & (3) & (4) & (5) & (6) & (7) & (8) \\
\hline \multirow[t]{2}{*}{$\operatorname{Ln}\left(\right.$ share $\left.^{\mathrm{bl} 1}\right)$} & 0.611 & $0.521 *$ & $0.645^{*}$ & $0.498^{*}$ & 0.385 & 0.109 & $0.842 *$ & $0.735^{* *}$ \\
\hline & $(0.312)$ & $(0.234)$ & $(0.308)$ & $(0.225)$ & $(0.375)$ & $(0.259)$ & $(0.337)$ & $(0.244)$ \\
\hline \multirow[t]{2}{*}{ Interaction } & 0.285 & -0.286 & -1.203 & -0.038 & 0.674 & $1.023 * *$ & -0.991 & $-1.042 *$ \\
\hline & $(0.901)$ & $(0.672)$ & (1.328) & (1.344) & $(0.492)$ & $(0.383)$ & $(0.617)$ & $(0.486)$ \\
\hline \multirow[t]{2}{*}{ Ln (IMMIGRANT) } & $0.270 * *$ & $0.264 * *$ & $0.270 * *$ & $0.264 * *$ & $0.270 * *$ & $0.264 * *$ & $0.269 * *$ & $0.263 * *$ \\
\hline & $(0.018)$ & $(0.014)$ & $(0.018)$ & $(0.014)$ & $(0.018)$ & $(0.014)$ & $(0.018)$ & $(0.014)$ \\
\hline \multirow[t]{2}{*}{$\operatorname{Ln}\left(y^{*} y\right)$} & 0.118 & 0.319 & 0.120 & 0.317 & 0.126 & 0.325 & 0.123 & 0.324 \\
\hline & $(0.323)$ & $(0.247)$ & $(0.323)$ & $(0.247)$ & $(0.323)$ & $(0.248)$ & $(0.323)$ & $(0.247)$ \\
\hline \multirow[t]{2}{*}{ Colony } & $0.572 * *$ & $0.494 * *$ & $0.728 * *$ & $0.496^{*}$ & $0.576^{* *}$ & $0.492 * *$ & $0.572 * *$ & $0.488^{* *}$ \\
\hline & $(0.134)$ & $(0.107)$ & $(0.226)$ & $(0.205)$ & $(0.134)$ & $(0.107)$ & $(0.134)$ & $(0.107)$ \\
\hline \multirow[t]{2}{*}{ Religion } & -0.011 & $0.190 * *$ & -0.009 & $0.190 * *$ & -0.089 & 0.072 & -0.013 & $0.188 * *$ \\
\hline & $(0.066)$ & $(0.052)$ & $(0.066)$ & $(0.052)$ & $(0.089)$ & $(0.068)$ & $(0.066)$ & $(0.052)$ \\
\hline \multirow[t]{2}{*}{ Legal } & 0.074 & -0.037 & 0.076 & -0.039 & 0.076 & -0.038 & 0.211 & 0.103 \\
\hline & $(0.067)$ & $(0.057)$ & $(0.066)$ & $(0.057)$ & $(0.067)$ & $(0.057)$ & $(0.108)$ & $(0.085)$ \\
\hline \multirow[t]{2}{*}{ Ln(distance) } & $-1.182 * *$ & $-1.286^{* *}$ & $-1.183^{* *}$ & $-1.286^{* *}$ & $-1.180 * *$ & $-1.283 * *$ & $-1.173 * *$ & $-1.277 * *$ \\
\hline & $(0.068)$ & $(0.056)$ & $(0.068)$ & $(0.056)$ & $(0.068)$ & $(0.056)$ & $(0.069)$ & $(0.056)$ \\
\hline \multirow[t]{2}{*}{ Contiguity } & 0.004 & 0.127 & 0.001 & 0.131 & 0.0118 & 0.148 & -0.007 & 0.124 \\
\hline & $(0.147)$ & $(0.121)$ & $(0.146)$ & $(0.121)$ & $(0.146)$ & $(0.120)$ & $(0.146)$ & $(0.121)$ \\
\hline \multirow[t]{2}{*}{ RTA } & -0.055 & $-0.155^{*}$ & -0.057 & $-0.153^{*}$ & -0.052 & $-0.147^{*}$ & -0.062 & $-0.158^{*}$ \\
\hline & $(0.085)$ & $(0.074)$ & $(0.085)$ & $(0.074)$ & $(0.085)$ & $(0.074)$ & $(0.085)$ & $(0.075)$ \\
\hline \multirow[t]{2}{*}{ Comlang } & 0.250 & $0.232 *$ & $0.284^{* *}$ & $0.198^{*}$ & $0.274^{*}$ & $0.185^{*}$ & $0.288 * *$ & $0.201^{*}$ \\
\hline & $(0.157)$ & $(0.115)$ & $(0.109)$ & $(0.085)$ & $(0.108)$ & $(0.084)$ & $(0.109)$ & $(0.085)$ \\
\hline Observations & 4,806 & 4,923 & 4,806 & 4,923 & 4,806 & 4,923 & 4,806 & 4,923 \\
\hline R-squared & 0.797 & 0.837 & 0.797 & 0.837 & 0.797 & 0.837 & 0.797 & 0.837 \\
\hline
\end{tabular}

Note: Dep. Var. is the log of total value of trade in US dollars (import or export). Estimation method: OLS. Column heading indicates the variable that is interacted with the variable Lshareb1. All regressions include time, host, and home fixed effects; robust standard errors are clustered on country pairs. ${ }^{* *}$ - significant at $1 \%,{ }^{*}$ significant at $5 \%$. 
Figure 1A: Business networks and share of exports to top migration sending partners in some representative countries

\section{France}

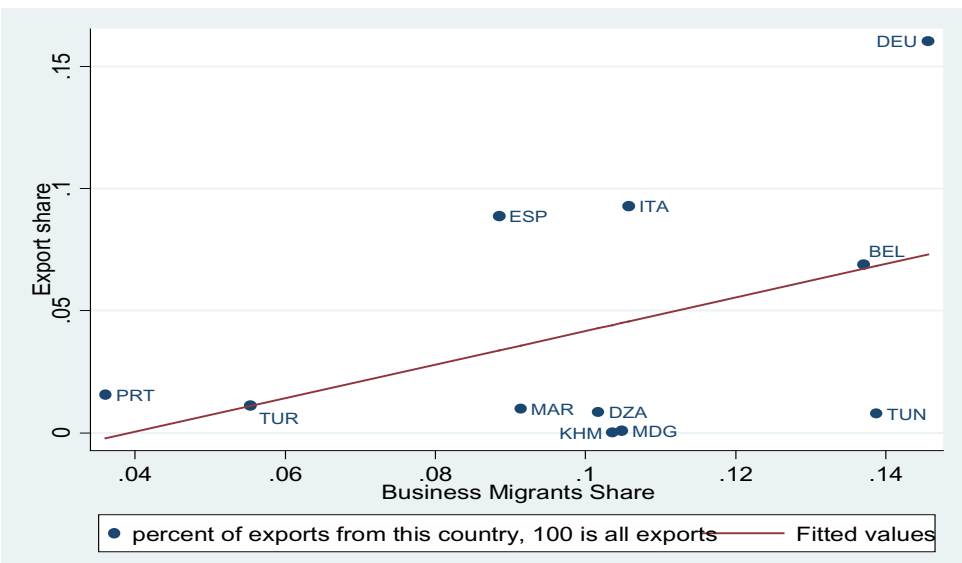

Portugal

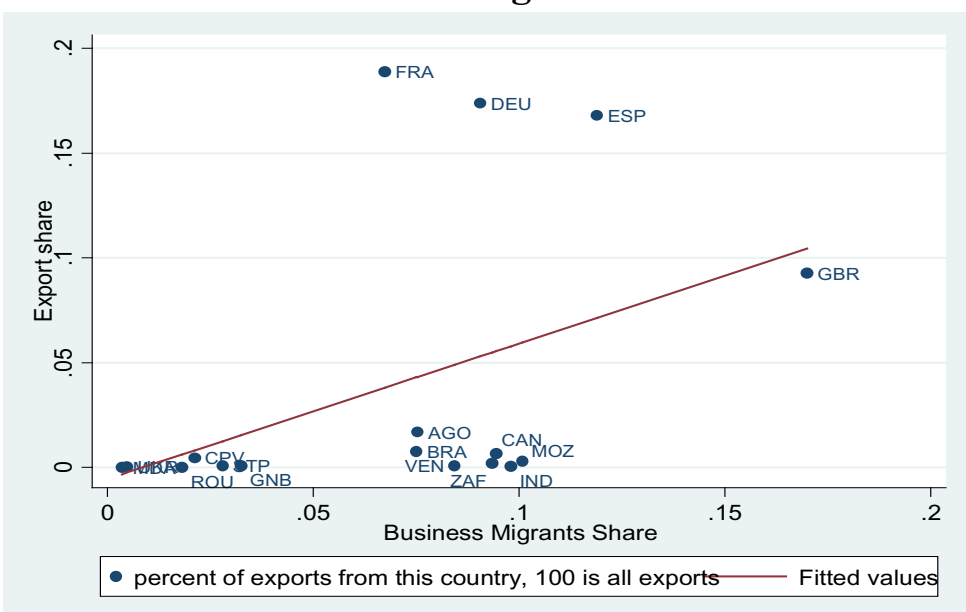

UK

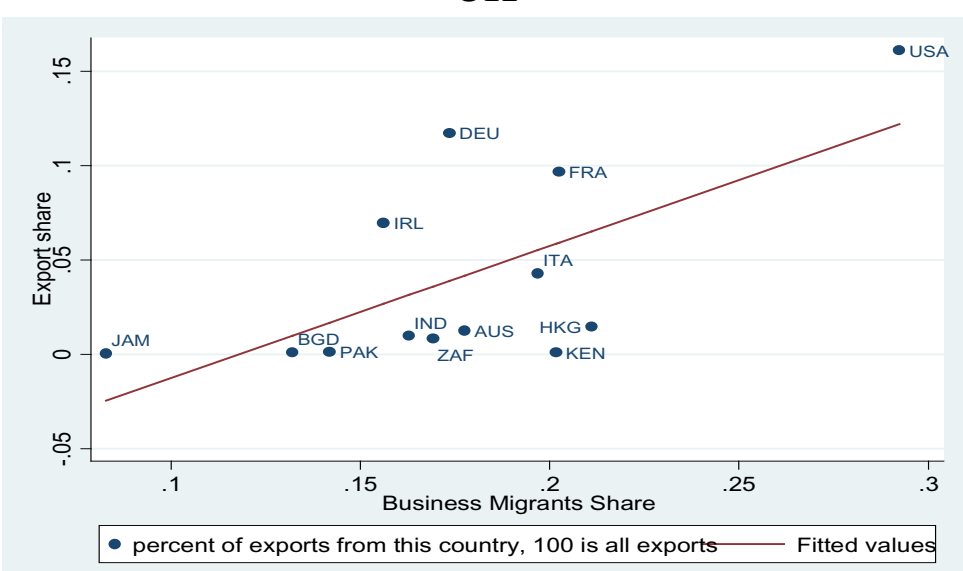

Spain

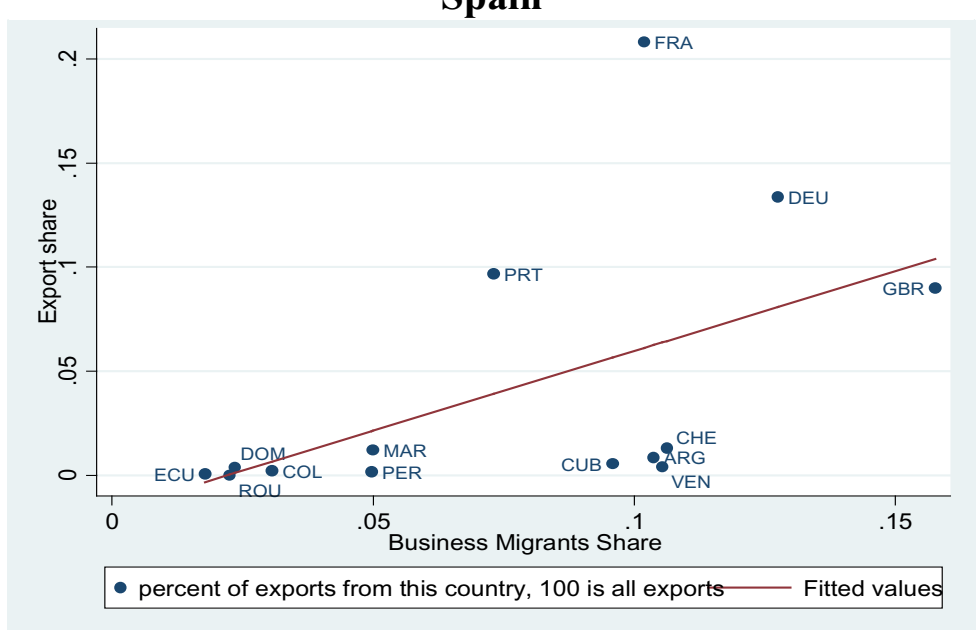


Figure 1B: Total share of immigrants and share of exports to top migration sending partners in some representative countries

\section{France}

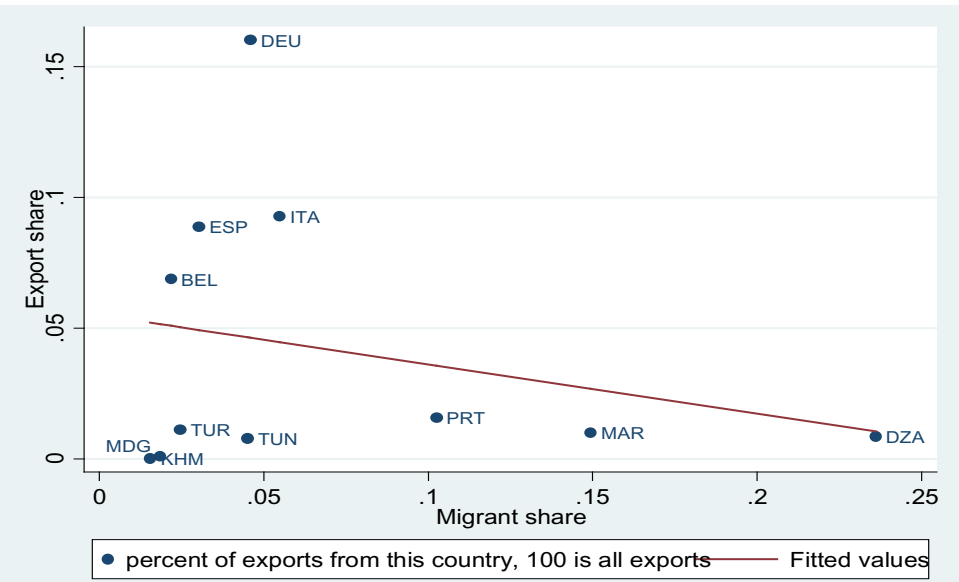

Portugal

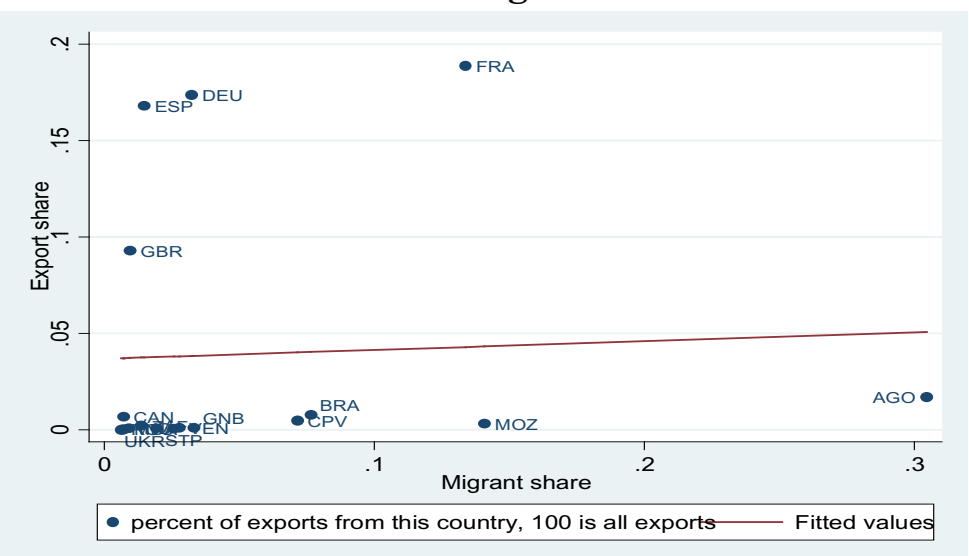

UK

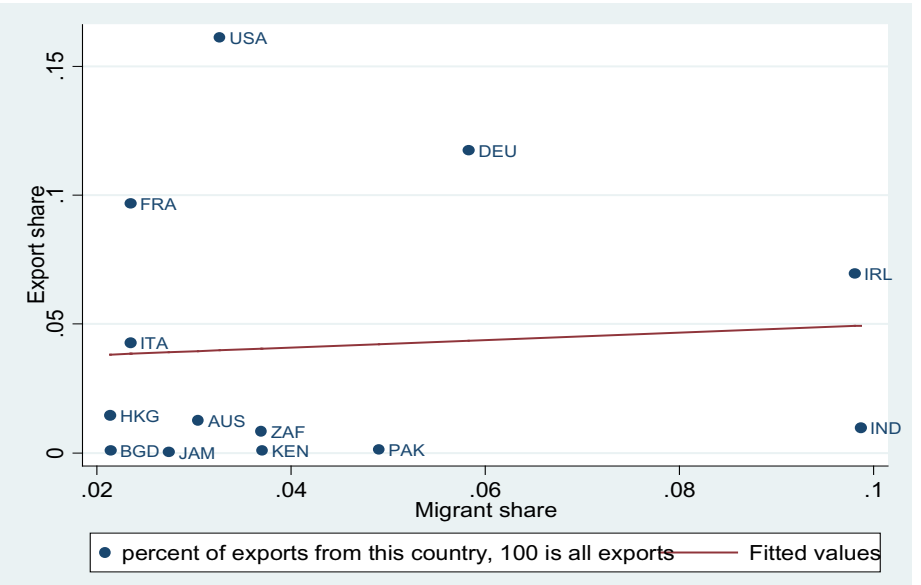

Spain

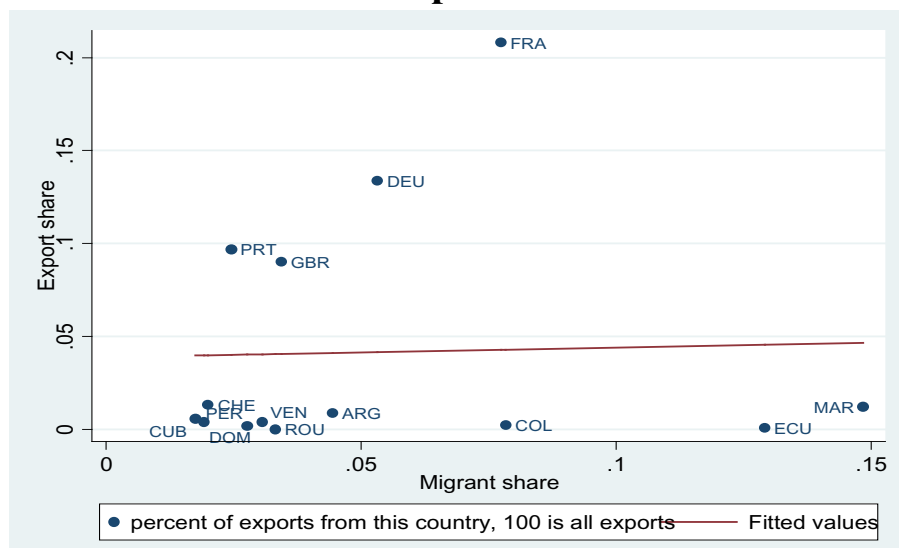




\section{Appendix 1. Variables Description and Sample Statistics}

\begin{tabular}{|c|c|c|c|c|c|c|}
\hline Variable & Description & Obs & Mean & St. D. & Min & Max \\
\hline LExports & Log of total value of exports in US dollars & 4923 & 16,48 & 3,22 & 2,78 & 26,25 \\
\hline LImports & og of total value of imports in US dollars & 4806 & 16,15 & 3,66 & 2,56 & 25,92 \\
\hline $\operatorname{Ln}\left(\right.$ total $\left.^{\mathrm{bl}}\right)$ & $\begin{array}{l}\text { Log of total number of immigrants in occupations } \\
\text { of ISCO Group 1, in a given country pair }\end{array}$ & 4923 & 2,84 & 2,48 & 0,00 & 12,84 \\
\hline $\operatorname{Ln}\left(\right.$ share $\left.^{\mathrm{b} 1}\right)$ & $\begin{array}{l}\text { Log of the ratio of total number of immigrants in } \\
\text { occupations of ISCO Group 1, over the total } \\
\text { number of active immigrant population in a given } \\
\text { country pair }\end{array}$ & 4923 & $-2,07$ & 1,00 & $-8,52$ & 0,00 \\
\hline $\operatorname{Ln}\left(\right.$ share $\left.^{\mathrm{b} 59}\right)$ & Same, for ISCO Groups 5 and 9 & 4923 & $-1,73$ & 0,75 & $-5,72$ & 0,00 \\
\hline $\operatorname{Ln}\left(\operatorname{share}^{\mathrm{nb}}\right)$ & Same, for all other ISCO groups & 4923 & $-1,15$ & 0,19 & $-2,08$ & 0,00 \\
\hline Ln(IMMIGRANT) & $\begin{array}{l}\text { Log of total number of active immigrant } \\
\text { population, aged } 15+\text { in a given country pair }\end{array}$ & 4923 & 4,96 & 2,75 & 0,69 & 14,54 \\
\hline $\operatorname{Ln}\left(y^{*} y\right)$ & $\begin{array}{l}\text { Log of the product of origin and destination } \\
\text { countries current non-deflated GDPs, in US dollars }\end{array}$ & 4923 & 49,26 & 2,61 & 40,96 & 58,31 \\
\hline $\operatorname{Ln}($ distance $)$ & $\begin{array}{l}\text { Log of population-weighted distance between } \\
\text { countries, } \mathrm{km}\end{array}$ & 4923 & 8,50 & 0,91 & 5,08 & 9,89 \\
\hline Contiguity & 1 for countries sharing a border & 4923 & 0,04 & 0,19 & 0,00 & 1,00 \\
\hline Comlang & $\begin{array}{l}1 \text { for countries sharing a common official or } \\
\text { primary language }\end{array}$ & 4923 & 0,15 & 0,36 & 0,00 & 1,00 \\
\hline Colony & 1 for countries ever having a colonial relationship & 4923 & 0,04 & 0,20 & 0,00 & 1,00 \\
\hline RTA & $\begin{array}{l}1 \text { for countries having a regional trading } \\
\text { agreements in force }\end{array}$ & 4923 & 0,16 & 0,36 & 0,00 & 1,00 \\
\hline $\operatorname{Ln}\left(\right.$ share $\left.^{\text {edu2 }}\right)$ & $\begin{array}{l}\text { Log of the ratio of immigrants with secondary } \\
\text { education over the total number of migrants in a } \\
\text { given country pair plus one }\end{array}$ & 4442 & $-1,08$ & 0,58 & $-0,52$ & 0,00 \\
\hline $\operatorname{Ln}\left(\right.$ share $\left.^{\text {edu3 }}\right)$ & & 4691 & $-0,91$ & 0,72 & $-8,10$ & 0,00 \\
\hline $\operatorname{Ln}\left(\right.$ total $\left.^{\text {edul }}\right)$ & $\begin{array}{l}\text { Log of the total number of immigrants with } \\
\text { primary education in a given country pair plus one }\end{array}$ & 3911 & 4,01 & 2,70 & 0,00 & 13,01 \\
\hline $\operatorname{Ln}\left(\right.$ total $\left.^{\text {edu2 }}\right)$ & Same for secondary education & 4442 & 4,21 & 2,63 & 0,00 & 14,09 \\
\hline $\operatorname{Ln}\left(\right.$ total $\left.^{\text {edu3 }}\right)$ & $\begin{array}{l}\text { Same for tertiary education } \\
\text { Log of the ratio of immigrants in ISCO Group } 1 \\
\text { and having primary education, over the total } \\
\text { number of immigrants in a given country pair plus }\end{array}$ & 4691 & 4,17 & 2,55 & 0,00 & 13,30 \\
\hline $\operatorname{Ln}\left(\right.$ share $\left.^{\text {b1_edu1 }}\right)$ & 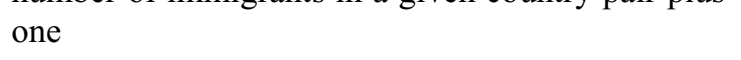 & 4923 & $-4,21$ & 1,27 & $-10,1$ & 0,00 \\
\hline $\operatorname{Ln}\left(\right.$ share $\left.^{\text {b1_edu2 }}\right)$ & Same for secondary education & 4923 & $-3,26$ & 1,08 & $-8,69$ & 0,00 \\
\hline $\operatorname{Ln}\left(\right.$ share $\left.^{\text {b1_edu3 }}\right)$ & Same for tertiary education & 4923 & $-2,66$ & 1,12 & $-8,99$ & 0,00 \\
\hline $\operatorname{Ln}\left(\right.$ share $\left.^{\text {nb_edu2 }}\right)$ & Same for non-business network, secondary & 4442 & $-1,21$ & 0,59 & $-5,19$ & 0,00 \\
\hline $\operatorname{Ln}\left(\right.$ share $\left.^{\text {nb_edu3 }}\right)$ & Same for non-business network, tertiary & 4691 & $-1,10$ & 0,73 & $-8,11$ & 0,00 \\
\hline
\end{tabular}




\title{
Appendix 2. Occupations under Group 1 of ISCO-88 Classification
}

\author{
11 Legislators and senior officials \\ 111 Legislators and senior government officials \\ 114 Senior officials of special-interest organizations \\ 1141 Senior officials of political party organizations \\ 1142 Senior officials of employers', workers' and other economic-interest organizations \\ 1143 Senior officials of humanitarian and other special-interest organizations \\ 12 Corporate managers \\ 121 Directors and chief executives \\ 122 Production and operations managers
}

1221 Production and operations managers in agriculture, hunting, forestry and fishing

1222 Production and operations managers in manufacturing

1223 Production and operations managers in construction

1224 Production and operations managers in wholesale and retail trade

1225 Production and operations managers in restaurants and hotels

1226 Production and operations managers in transport, storage and communications

1227 Production and operations managers in business services enterprises

1228 Production and operations managers in personal care, cleaning and related services

1229 Production and operations managers not elsewhere classified

123 Other specialist managers

1231 Finance and administration managers

1232 Personnel and industrial relations managers

1233 Sales and marketing managers

1234 Advertising and public relations managers

1235 Supply and distribution managers

1236 Computing services managers

1237 Research and development managers

1239 Other specialist managers not elsewhere classified

13 Managers of small enterprises

131 Managers of small enterprises

1311 Managers of small enterprises in agriculture, hunting, forestry and fishing

1312 Managers of small enterprises in manufacturing

1313 Managers of small enterprises in construction

1314 Managers of small enterprises in wholesale and retail trade

1315 Managers of small enterprises of restaurants and hotels

1316 Managers of small enterprises in transport, storage and communications

1317 Managers of small enterprises of business services enterprises

1318 Managers of small enterprises in personal care, cleaning and related services

1319 Managers of small enterprises not elsewhere classified 


\section{Appendix 3. Other Occupations with Business-Oriented Potential}

52 Models, salespersons and demonstrators

522 Shop, stall and market salespersons and demonstrators

5220 Shop, stall and market salespersons and demonstrators

$91 \quad$ Sales and services elementary occupations

911 Street vendors and related workers

9111 Street vendors

9113 Door-to-door and telephone salespersons 


\section{LIST OF WORKING PAPERS RELEASED BY CEPII}

An Exhaustive list is available on the website: |lwww.cepii.fr.

No

2011-25 Notes on CEPII's distances measures: The GeoDist database

2011-24 Estimations of Tariff Equivalents for the Services Sectors

2011-23 Economic Impact of Potential Outcome of the DDA

2011-22 More Bankers, more Growth? Evidence from OECD Countries

2011-21 EMU, EU, Market Integration and Consumption Smoothing

2011-20 Real Time Data and Fiscal Policy Analysis

2011-19 On the inclusion of the Chinese renminbi in the SDR basket

2011-18 Unilateral trade reform, Market Access and Foreign Competition: the Patterns of Multi-Product Exporters

2011-17 The "Forward Premium Puzzle" and the Sovereign Default Risk

2011-16 Occupation-Education Mismatch of Immigrant Workers in Europe: Context and Policies

2011-15 Does Importing More Inputs Raise Exports? Firm Level Evidence from France

2011-14 Joint Estimates of Automatic and Discretionary Fiscal Policy: the OECD 1981-2003

2011-13 Immigration, vieillissement démographique et financement de la protection sociale : une évaluation par l'équilibre général calculable appliqué à la France
Authors

T. Mayer \& S. Zignago

L. Fontagné, A. Guillin \& C. Mitaritonna

Y. Devreux \& L. Fontagné

G. Capelle-Blancard \& C. Labonne

A. Christev \& J. Mélitz

J. Cimadomo

A. Bénassy-Quéré \& D. Capelle

M. Bas \& P. Bombarda

V. Coudert \& V. Mignon

M. Aleksynska \& A. Tritah

M. Bas \& V. Strauss-Kahn

J. Darby \& J. Mélitz

X. Chojnicki \& L. Ragot 
No

Title

2011-12 The Performance of Socially Responsible Funds: Does the Screening Process Matter?

2011-11 Market Size, Competition, and the Product Mix of Exporters

2011-10 The Trade Unit Values Database

2011-09 Carbon Price Drivers: Phase I versus Phase II Equilibrium

2011-08 Rebalancing Growth in China: An International Perspective

2011-07 Economic Integration in the EuroMed: Current Status and Review of Studies

2011-06 The Decision to Import Capital Goods in India: Firms' Financial Factors Matter

2011-05 FDI from the South: the Role of Institutional Distance and Natural Resources

2011-04b What International Monetary System for a fast-changing World Economy?

2011-04a Quel système monétaire international pour une économie mondiale en mutation rapide?

2011-03 China's Foreign Trade in the Perspective of a more Balanced Economic Growth

2011-02 The Interactions between the Credit Default Swap and the Bond Markets in Financial Turmoil

2011-01 Comparative Advantage and Within-Industry Firms Performance

2010-33 Export Performance and Credit Constraints in China

2010-32 Export Performance of China's Domestic Firms: the Role of Foreign Export Spillovers

2010-31 Wholesalers in International Trade
Authors

G. Capelle-Blancard \& S. Monjon

T. Mayer, M. Melitz \& G. Ottaviano

A. Berthou \& C. Emlinger

A. Creti, P.-A. Jouvet \& V. Mignon

A. Bénassy-Quéré,B. Carton \& L. Gauvin

J. Jarreau

A. Berthou \& M. Bas

M. Aleksynska \& O. Havrylchyk

A. Bénassy-Quéré \& J. Pisani-Ferry

A. Bénassy-Quéré \& J. Pisani-Ferry

G. Gaulier, F. Lemoine \& D. Ünal

V. Coudert \& M. Gex

M. Crozet \& F. Trionfetti

J. Jarreau \& S. Poncet

F. Mayneris \& S. Poncet

M. Crozet, G. Lalanne \& S. Poncet 
No

Title

2010-30 TVA et taux de marge : une analyse empirique sur données d'entreprises

2010-29 Economic and cultural assimilation and integration of immigrants in europe

2010-28 Les firmes françaises dans le commerce de service

2010-27 The World Economy in 2050: a Tentative Picture

2010-26 Determinants and Pervasiveness of the Evasion of Customs Duties

2010-25 On the Link between Credit Procyclicality and Bank Competition

2010-24 Are Derivatives Dangerous? A Literature Survey

2010-23 BACI: International Trade Database at the Product-Level - The 1994-2007 Version

2010-22 Indirect Exporters

2010-21 Réformes des retraites en France : évaluation de la mise en place d'un système par comptes notionnels

2010-20 The Art of Exceptions: Sensitive Products in the Doha Negotiations

2010-19 Measuring Intangible Capital Investment: an Application to the "French Data

2010-18 Clustering the Winners: The French Policy of Competitiveness Clusters

2010-17 The Credit Default Swap Market and the Settlement of Large Defauts

2010-16 The Impact of the 2007-10 Crisis on the Geography of Finance

2010-15 Socially Responsible Investing: It Takes more than Words
Authors

P. Andra, M. Carré \& A. Bénassy-Quéré

M. Aleksynska \& Y. Algan

G. Gaulier, E. Milet \& D. Mirza

J. Fouré, A. Bénassy-Quéré \& L. Fontagné

S. Jean \& C. Mitaritonna

V. Bouvatier, A. Lopez-Villavicencio \& V. Mignon

G. Capelle-Blancard

G. Gaulier \& S. Zignago

F. McCann

X. Chojnicki \& R. Magnani

C. Gouel, C. Mitaritonna \& M.P. Ramo

V. Delbecque \& L. Nayman L. Fontagné, P. Koenig, F. Mayneris \& S. Poncet

V. Coudert \& M. Gex

G. Capelle-Blancard \& Y. Tadjeddine

G. Capelle-Blancard \& S. Monjon 
No

Title

Authors

2010-14 A Case for Intermediate Exchange-Rate Regimes

V. Salins

\& A. Bénassy-Quéré

2010-13 Gold and Financial Assets: Are they any Safe Havens in Bear Markets?

V. Coudert \& H. Raymond

2010-12 European Export Performance

A. Cheptea, L. Fontagné \& S. Zignago

2010-11 The Effects of the Subprime Crisis on the Latin American Financial Markets: An Empirical Assessment

2010-10 Foreign Bank Presence and its Effect on Firm Entry and Exit in Transition Economies

2010-09 The Distorted Effect of Financial Development on International Trade Flows

2010-08 Exchange Rate Flexibility across Financial Crises

2010-07 Crises and the Collapse of World Trade: the Shift to Lower Quality

2010-06 The heterogeneous effect of international outsourcing on firm productivity

2010-05 Fiscal Expectations on the Stability and Growth Pact: Evidence from Survey Data

2010-04 Terrorism Networks and Trade: Does the Neighbor Hurt

2010-03 Wage Bargaining and the Boundaries of the Multinational Firm

2010-02 Estimation of Consistent Multi-Country FEERs

2010-01 The Elusive Impact of Investing Abroad for Japanese Parent Firms: Can Disaggregation According to FDI Motives Help

G. Dufrénot, V. Mignon \& A. Péguin-Feissolle

O. Havrylchyk

A. Berthou

V. Coudert, C. Couharde \& V. Mignon

A. Berthou \& C. Emlinger

F. McCann

M. Poplawski-Ribeiro \& J.C. Rüle

J. de Sousa, D. Mirza $\&$ T. Verdier

M. Bas \& J. Carluccio

B. Carton \& K. Hervé

L. Hering, T. Inui \& S. Poncet 
Organisme public d'étude et de recherche en économie internationale, le CEPII est placé auprès du Centre d'Analyse Stratégique. Son programme de travail est fixé par un conseil composé de responsables de l'administration et de personnalités issues des entreprises, des organisations syndicales et de l’Université.

Les documents de travail du CEPII mettent à disposition du public professionnel des travaux effectués au CEPII, dans leur phase d'élaboration et de discussion avant publication définitive. Les documents de travail sont publiés sous la responsabilité de la direction du CEPII et n'engagent ni le conseil du Centre, ni le Centre d'Analyse Stratégique. Les opinions qui y sont exprimées sont celles des auteurs.

Les documents de travail du CEPII sont disponibles sur le site : http//www.cepii.fr 